\title{
Article \\ Surface Modification of a Nickel-Free Austenitic Stainless Steel by Low-Temperature Nitriding
}

\author{
Francesca Borgioli *(D), Emanuele Galvanetto and Tiberio Bacci \\ Department of Industrial Engineering, University of Florence, Via S. Marta 3, 50139 Florence, Italy; \\ emanuele.galvanetto@unifi.it (E.G.); tiberio.bacci@unifi.it (T.B.) \\ * Correspondence: francesca.borgioli@unifi.it
}

check for updates

Citation: Borgioli, F.; Galvanetto, E.; Bacci, T. Surface Modification of a Nickel-Free Austenitic Stainless Steel by Low-Temperature Nitriding. Metals 2021, 11, 1845. https:// doi.org/10.3390/met11111845

Academic Editor:

Carlos Garcia-Mateo

Received: 30 September 2021

Accepted: 15 November 2021

Published: 17 November 2021

Publisher's Note: MDPI stays neutral with regard to jurisdictional claims in published maps and institutional affiliations.

Copyright: (c) 2021 by the authors. Licensee MDPI, Basel, Switzerland. This article is an open access article distributed under the terms and conditions of the Creative Commons Attribution (CC BY) license (https:// creativecommons.org/licenses/by/ $4.0 /)$.

\begin{abstract}
Low-temperature nitriding allows to improve surface hardening of austenitic stainless steels, maintaining or even increasing their corrosion resistance. The treatment conditions to be used in order to avoid the precipitation of large amounts of nitrides are strictly related to alloy composition. When nickel is substituted by manganese as an austenite forming element, the production of nitridefree modified surface layers becomes a challenge, since manganese is a nitride forming element while nickel is not. In this study, the effects of nitriding conditions on the characteristics of the modified surface layers obtained on an austenitic stainless steel having a high manganese content and a negligible nickel one, a so-called nickel-free austenitic stainless steel, were investigated. Microstructure, phase composition, surface microhardness, and corrosion behavior in $5 \% \mathrm{NaCl}$ were evaluated. The obtained results suggest that the precipitation of a large volume fraction of nitrides can be avoided using treatment temperatures lower than those usually employed for nickel-containing austenitic stainless steels. Nitriding at 360 and $380{ }^{\circ} \mathrm{C}$ for duration up to $5 \mathrm{~h}$ allows to produce modified surface layers, consisting mainly of the so-called expanded austenite or $\gamma_{\mathrm{N}}$, which increase surface hardness in comparison with the untreated steel. Using selected conditions, corrosion resistance can also be significantly improved.
\end{abstract}

Keywords: austenitic stainless steels; Ni-free austenitic stainless steels; low-temperature nitriding; expanded austenite; S-phase; hardening; corrosion resistance

\section{Introduction}

The face-centered cubic (f.c.c.) structure of austenite is maintained in austenitic stainless steels owing to the use of austenite forming elements. Among these alloy elements, nickel is widely used, since it allows to improve ductility and toughness, and it has a positive effect on corrosion resistance, promoting repassivation [1]. However, this element is rather expensive and it contributes to a significant percentage of the energy used in the fabrication of stainless steels [2]. High nickel content (usually $8 \%$ or higher) is present in CrNi-based AISI 300 series stainless steels, which are used in many industrial fields. The substitution of part of the nickel content with manganese and nitrogen is the basis of CrMnbased AISI 200 series stainless steels, which are cheaper than AISI 300 series alloys, but they have high strength and/or good formability depending on composition [3]. The presence of nickel in austenitic stainless steels is a major concern when these alloys are used for biomedical applications. In fact, nickel-ion release, due to corrosion or wear phenomena, may cause adverse effects ranging from allergic reactions to genotoxic and mutagenic activities [4,5]. In order to improve biocompatibility, austenitic stainless steels with a negligible nickel content, usually known as nickel-free (Ni-free) stainless steels, have been developed [4-8]. In these alloys, in which nickel content is lower than $0.3 \mathrm{wt} . \%$, the austenite forming elements are usually manganese (9.5-24 wt.\%) and nitrogen (0.45-1.1 wt.\%), and molybdenum is added for increasing localized corrosion resistance $[4,5,8]$.

Ni-free austenitic stainless steels show improved strength, wear resistance, and corrosion resistance, in comparison with the widely used AISI 316L steel $[4,5,9,10]$. However, 
some applications may require to increase surface hardness and tribological properties of these steels, as well as corrosion resistance in chloride-ion containing solutions, like body fluids. Among the different surface engineering strategies for austenitic stainless steels, low-temperature diffusion treatments are particularly interesting and have been the subject of many studies in recent years [11-15]. By using atmospheres containing nitrogen, carbon, or nitrogen and carbon, it is possible to avoid the precipitation of chromium nitrides or carbides performing the treatments at temperatures that allow the interstitial atoms to diffuse in the steel, while the substitutional atoms ( $\mathrm{Fe}, \mathrm{Cr}, \mathrm{Ni}, \mathrm{Mn}, \mathrm{Mo}$ ), which diffuse more slowly, can be considered relatively "immobile" in the lattice [16-18]. In these conditions, modified surface layers form, consisting of a supersaturated solid solution of nitrogen and/or carbon, well beyond the solubility limit, in the expanded and distorted austenite lattice [7,11-15], known as expanded austenite [12,14] or S-phase [11,13,15], or $\gamma_{\mathrm{N}}$ (for the nitrogen-rich one) and $\gamma_{C}$ (for the carbon-rich one) $[15,16]$. Nitrogen-rich expanded austenite, $\gamma_{\mathrm{N}}$, has a nitrogen content up to $\sim 38$ at.\% [19] and high hardness (up to about $1450 \mathrm{HK}[20])$. The maximum carbon content in the carbon-rich expanded austenite, $\gamma_{\mathrm{C}}$, is lower, about 19 at.\% [21], so that hardness is slightly lower (up to about $950 \mathrm{HK}$ [22]). Besides surface hardening, the formation of modified surface layers consisting of expanded austenite allows to improve tribological $[13,15,23,24]$ and fatigue $[13,15,23,25]$ properties, and corrosion resistance in chloride-ion containing solutions [13,15,26]. The fundamental treatment parameter that allows to retain chromium in solid solution and avoid the precipitation of nitrides and carbides, deleterious for corrosion resistance, is treatment temperature. For nitriding treatment, temperatures lower than $450{ }^{\circ} \mathrm{C}$ should be used $[7,23]$, while for carburizing, the limit temperature is usually regarded as $550{ }^{\circ} \mathrm{C}$ [23]. Alloy composition plays also an important role in influencing the formation of precipitates. The presence of nickel, as in AISI 300 series steels, tends to hinder nitride and/or carbide precipitation, while, when nickel content is reduced and a fairly high amount of manganese is present, as in the AISI 200 series steels, nitrides may precipitate at temperatures at which they do not form in AISI 300 series steels, since manganese is a nitride forming element [27]. Few studies have been carried out on austenitic stainless steels having a negligible nickel content and a high manganese one, as Ni-free stainless steels. It is well assessed that in this steel type, low-temperature carburizing is able to produce modified surface layers consisting of a carbon-rich expanded austenite having high hardness and good corrosion resistance [28-30]. The effects of low-temperature nitriding are more controversial and the studies on this topic are even more limited. Buhagiar [31] and Buhagiar et al. [28] reported the formation of a fairly large volume fraction of nitrides in P558 (ASTM F2581) Ni-free austenitic stainless steel nitrided at $430{ }^{\circ} \mathrm{C}$, while with these treatment conditions, nitride-free modified surface layers are produced in CrNi-based AISI 316LVM. Thus, it has been suggested that modified surface layers without nitride precipitation are almost impossible to be obtained [13] in this Ni-free steel. However, in our previous study [26], nitrides were not detected when the P558 steel was nitrided at 360 and $380{ }^{\circ} \mathrm{C}$ for $3 \mathrm{~h}$.

Owing to the lack of extensive information in the international literature on the lowtemperature nitriding of austenitic stainless steels with a high manganese content and a negligible nickel one, the aim of this study has been to investigate the effects of treatment conditions on the characteristics of the modified surface layers obtained on a Ni-free austenitic stainless steel. Nitriding was performed by means of the glow-discharge process and the treatment conditions were chosen on the basis of our previous studies [26,27], varying temperature, duration, and treatment atmosphere. Microstructure, phase composition, surface microhardness, and corrosion behavior in a $5 \% \mathrm{NaCl}$ solution of the nitrided samples were studied, and the results were compared also with those of the untreated alloy. 


\section{Materials and Methods}

A commercial Ni-free austenitic stainless steel PANACEA P558 (Böhler Edelstahl Gmbh \& Co KG, Kapfenberg, Austria, through Böhler Sales Division of Böhler Uddeholm Italia S.p.A., Italy)) was employed, having the following chemical composition (wt.\%): C 0.2, Cr 18.0, Ni 0.09, Mn 10.5, Mo 3.0, N 0.48. Taking into account the chemical composition, the Pitting Resistance Equivalent Number (PREN) of the alloy was 35.6. The specimens, in form of disks (diameter: $18 \mathrm{~mm}$; thickness: $0.8 \mathrm{~mm}$ ) were cut from a rod (diameter: $18 \mathrm{~mm}$ ), and then they were ground with $\mathrm{SiC}$ papers and polished up to $6-\mu \mathrm{m}$ diamond suspension. X-ray diffraction analysis of the polished specimens showed that, besides austenite, $\gamma$-Fe, small volume fractions of $\varepsilon^{\prime}$ martensite (h.c.p.), and $\alpha^{\prime}$ martensite (b.c.t.) were present, probably due to the grinding and polishing procedure.

Glow-discharge nitriding treatments were performed in a laboratory plasma equipment, previously described [26]. The samples were put on an AISI 316L horizontal sample holder, connected to the cathode of a d.c. power supply; the sample holder was surrounded by an AISI 304 screen, which was grounded and worked as anode. The treatment temperature was measured by a chromel-alumel thermocouple inserted into the sample holder and it was controlled by the discharge current supplied by the d.c. power supply. After evacuating the treatment chamber up to a pressure of about $5 \mathrm{~Pa}$, a cathodic sputtering step was performed, in order to remove the natural passive film and obtain a homogenous nitriding, together with heating of the samples owing to ion- bombardment. During this process, a nitrogen incorporation also occurred, as reported in our previous papers [32,33]. The cathodic sputtering was carried out at $110 \mathrm{~Pa}$ with a constant current density of $(1.50 \pm 0.01) \mathrm{mA} \mathrm{cm}{ }^{-2}$, until a temperature of $300{ }^{\circ} \mathrm{C}$ was reached. Then, temperature, pressure and treatment atmosphere were changed to their nominal values. Nitriding conditions (temperature, $\mathrm{T}$, pressure, $\mathrm{p}$, duration, $\mathrm{t}$, and gas mixture composition) were chosen on the basis of our previous studies [26,27] and they are summarized in Table 1 together with the current density, i, and voltage drop, V. A series of treatments was performed at $360{ }^{\circ} \mathrm{C}$, at a constant pressure of $340 \mathrm{~Pa}$, for durations in the range $1-5 \mathrm{~h}$, using a gas mixture of $50 \mathrm{vol} . \% \mathrm{~N}_{2}$ and $50 \mathrm{vol} . \% \mathrm{H}_{2}$. Another series of treatments was performed at $380{ }^{\circ} \mathrm{C}$, $340 \mathrm{~Pa}$, for $3 \mathrm{~h}$, using gas mixtures of 50 vol. $\% \mathrm{~N}_{2}+50$ vol. $\% \mathrm{H}_{2}, 40$ vol. $\% \mathrm{~N}_{2}+60$ vol. $\% \mathrm{H}_{2}$, 40 vol. $\% \mathrm{~N}_{2}+50$ vol. $\% \mathrm{H}_{2}+10$ vol. $\% \mathrm{Ar}, 30$ vol. $\% \mathrm{~N}_{2}+50$ vol. $\% \mathrm{H}_{2}+20$ vol. $\% \mathrm{Ar}$, or 20 vol. $\% \mathrm{~N}_{2}+50$ vol. $\% \mathrm{H}_{2}+30$ vol. $\%$ Ar. Further samples were nitrided at $400{ }^{\circ} \mathrm{C}$, $500 \mathrm{~Pa}$, for $3 \mathrm{~h}$, using a gas mixture of $80 \mathrm{vol} . \% \mathrm{~N}_{2}+20$ vol. $\% \mathrm{H}_{2}$.

Table 1. Nitriding conditions. i: current density. V: voltage drop.

\begin{tabular}{|c|c|c|c|c|c|c|c|c|}
\hline Sample Type & $\begin{array}{c}\mathrm{T} \\
\left({ }^{\circ} \mathrm{C}\right)\end{array}$ & $\begin{array}{c}\mathrm{p} \\
(\mathrm{Pa})\end{array}$ & $\begin{array}{c}\mathbf{t} \\
(\mathbf{h})\end{array}$ & $\begin{array}{c}\mathrm{N}_{2} \\
\text { (vol.\%) }\end{array}$ & $\begin{array}{c}\mathrm{H}_{2} \\
\text { (vol.\%) }\end{array}$ & $\begin{array}{c}\text { Ar } \\
\text { (vol. } \% \text { ) }\end{array}$ & $\begin{array}{c}\mathrm{i} \\
\left(\mathrm{mA} \mathrm{cm}^{-2}\right)\end{array}$ & $\begin{array}{c}\mathrm{V} \\
(\mathrm{V})\end{array}$ \\
\hline $360-1 \mathrm{~h}$ & 360 & 340 & 1 & 50 & 50 & 0 & $1.15 \pm 0.05$ & $194 \pm 5$ \\
\hline $360-2 \mathrm{~h}$ & 360 & 340 & 2 & 50 & 50 & 0 & $1.15 \pm 0.05$ & $194 \pm 5$ \\
\hline $360-3 h$ & 360 & 340 & 3 & 50 & 50 & 0 & $1.15 \pm 0.05$ & $194 \pm 5$ \\
\hline $360-5 \mathrm{~h}$ & 360 & 340 & 5 & 50 & 50 & 0 & $1.15 \pm 0.05$ & $194 \pm 5$ \\
\hline $380-50 / 50 / 0$ & 380 & 340 & 3 & 50 & 50 & 0 & $1.19 \pm 0.05$ & $198 \pm 5$ \\
\hline $380-40 / 60 / 0$ & 380 & 340 & 3 & 40 & 60 & 0 & $1.18 \pm 0.05$ & $212 \pm 5$ \\
\hline $380-40 / 50 / 10$ & 380 & 340 & 3 & 40 & 50 & 10 & $1.20 \pm 0.05$ & $192 \pm 5$ \\
\hline $380-30 / 50 / 20$ & 380 & 340 & 3 & 30 & 50 & 20 & $1.23 \pm 0.05$ & $184 \pm 5$ \\
\hline $380-20 / 50 / 30$ & 380 & 340 & 3 & 20 & 50 & 30 & $1.24 \pm 0.05$ & $178 \pm 5$ \\
\hline 400 & 400 & 500 & 3 & 80 & 20 & 0 & $1.80 \pm 0.05$ & $200 \pm 5$ \\
\hline
\end{tabular}

The microstructure of untreated and nitrided specimens was examined using light and scanning electron (SEM; EVO MA 15, Carl Zeiss Microscopy GmbH, Jena, Germany) microscopy and energy-dispersive X-ray spectroscopy (EDS; INCA 250, Oxford Instruments NanoAnalysis, High Wycombe, UK). Cross-section and tapered section $\left(\sim 6^{\circ}\right)$ microstructures were delineated using acetic glyceregia etchant $\left(3 \mathrm{~mL} \mathrm{HCl}, 2 \mathrm{~mL} \mathrm{HNO}_{3}, 2 \mathrm{~mL}\right.$ acetic acid, 1 drop of glycerol) or glyceregia etchant ( $3 \mathrm{~mL}$ glycerol, $2 \mathrm{~mL} \mathrm{HCl}, 1 \mathrm{~mL} \mathrm{HNO}$ ). 
Phases were identified by means of X-ray diffraction (XRD) analysis ( $\mathrm{Cu} \mathrm{K} \alpha$ radiation) in Bragg-Brentano configuration (D8 Advance, Bruker AXS GmbH, Karlsruhe, Germany).

Surface microhardness measurements were performed on the surface of the samples using a Knoop indenter (load: 10, 25, 50, and $100 \mathrm{~g}_{\mathrm{f}}$ ). For each load, at least ten measurements were taken at different locations on each sample.

Corrosion behavior was studied in a $5 \% \mathrm{NaCl}$ solution at room temperature and in natural aerated conditions. A three-electrode flat cell, equipped with a platinum grid as counterelectrode and an $\mathrm{Ag} / \mathrm{AgCl}(3.5 \mathrm{M} \mathrm{KCl})$ reference electrode, was used. The sample surface area exposed to the electrolyte was $1 \mathrm{~cm}^{2}$. All the tests were performed after a $18 \mathrm{~h}$ delay. Electrochemical impedance spectroscopy (EIS) measurements were carried out at open circuit potential (OCP). The frequency range was between $10 \mathrm{kHz}$ and $25 \mathrm{mHz}$, with 10 points per decade and an $a c$ amplitude (rms) of $5 \mathrm{mV}$. A non-linear least square analysis software (EIS Spectrum Analyser [34]) was used for modeling EIS spectra. Potentiodynamic polarization tests were performed using a scan rate of $0.3 \mathrm{mV} \mathrm{s}^{-1}$.

\section{Results}

\subsection{Morphology and Microstructure}

The examination of the cross-section of the modified surface layers produced on lowtemperature nitrided austenitic stainless steels, as delineated by chemical etching, showed that they consisted of an outer layer, in which expanded austenite, $\gamma_{\mathrm{N}}$, was present, and an inner layer, consisting of a solid solution of interstitial atoms (nitrogen, carbon) in the slightly expanded austenite lattice, $\gamma(\mathrm{N}, \mathrm{C})$, as previously reported $[15,26]$. Both these layers were a modification of the austenite matrix and their characteristics depended on the nitriding conditions.

The microstructure of a sample nitrided at $400{ }^{\circ} \mathrm{C}, 500 \mathrm{~Pa}$, for $3 \mathrm{~h}$, using a gas mixture of $80 \mathrm{vol} . \% \mathrm{~N}_{2}+20 \mathrm{vol} . \% \mathrm{H}_{2}$ is shown in Figure 1a. Using similar treatment conditions, in AISI 316L samples nitrides were not able to form [27], while in the outer modified layer of Ni-free samples many strong etched zones, corresponding to nitrides, were observable. XRD analysis showed that, besides $\gamma_{\mathrm{N}}$, peaks of $\mathrm{CrN}$ (f.c.c.) and h.c.p.-based $\varepsilon$-type $\mathrm{M}_{2-3} \mathrm{~N}$ $\left(\mathrm{M}=\mathrm{Fe}, \mathrm{Cr}, \mathrm{Mn}, \mathrm{Mo}\right.$ ) nitride were detected (Figure $1 \mathrm{~b}$ ). The peaks of $\varepsilon-\mathrm{M}_{2-3} \mathrm{~N}$ overlapped those of the so-called nitrogen-induced h.c.p. martensite, $\varepsilon_{N^{\prime}}{ }^{\prime}$, which is a solid solution of nitrogen in the h.c.p. $\varepsilon^{\prime}$ martensite and forms as a consequence of the localized plastic deformations due to the formation of $\gamma_{\mathrm{N}}[35,36]$.

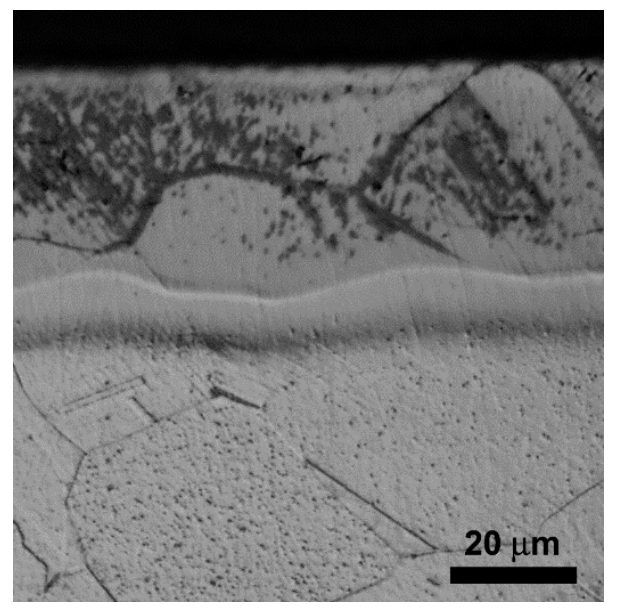

(a)

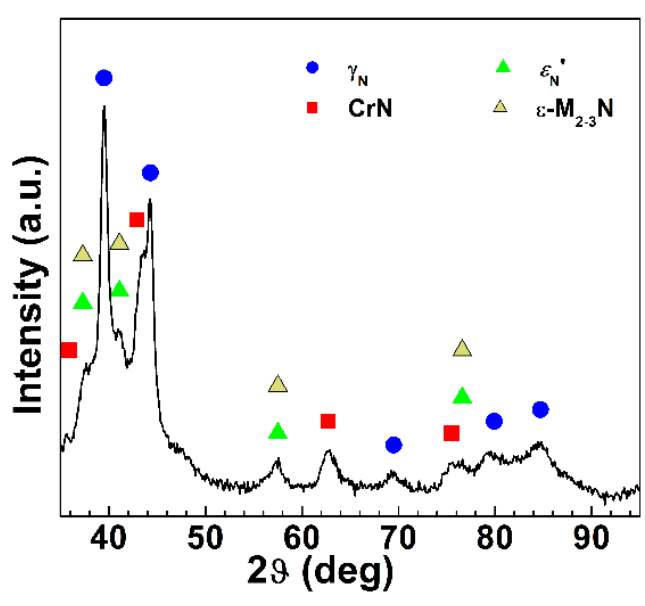

(b)

Figure 1. Micrograph (a) and X-ray diffraction pattern (b) of a sample nitrided at $400{ }^{\circ} \mathrm{C}, 500 \mathrm{~Pa}$, for $3 \mathrm{~h}$, using a gas mixture of $80 \mathrm{vol} . \% \mathrm{~N}_{2}+20 \mathrm{vol} . \% \mathrm{H}_{2}$. 
Reducing treatment temperature and nitrogen content in the treatment atmosphere, and performing nitriding at $380{ }^{\circ} \mathrm{C}, 340 \mathrm{~Pa}$, for $3 \mathrm{~h}$, with a gas mixture of $50 \mathrm{vol} . \% \mathrm{~N}_{2}+50 \mathrm{vol} . \% \mathrm{H}_{2}$, strong etched regions, as those present in the $400{ }^{\circ} \mathrm{C}$ nitrided samples, were not observed, suggesting that a large volume fraction of nitrides was not able to form. As shown in Figure $2 \mathrm{a}$, in the outer modified layer of this sample type many shear lines were present and they extended deeply in the layer, while the inner modified layer was almost featureless. The thickness of the outer layer, $d_{o}$, was $(3.5 \pm 0.2) \mu \mathrm{m}$, and that of the inner layer, $d_{i}$, was $(3.0 \pm 0.2) \mu \mathrm{m}$. In the XRD patterns, besides the peaks belonging to $\gamma_{\mathrm{N}}$, those of the $\varepsilon_{N}{ }^{\prime}$ martensite were detected (Figure $3 a$ ). The presence of the $\varepsilon-\mathrm{M}_{2-3} \mathrm{~N}$ nitride, which may form as a consequence of a distortion of the $\varepsilon_{\mathrm{N}}{ }^{\prime}$ phase and an ordering of nitrogen atoms [37], cannot be ruled out, even if distinct peaks of this phase were not observable; for this reason, the symbol of $\varepsilon-\mathrm{M}_{2-3} \mathrm{~N}$ is depicted in parenthesis. When the nitrogen content in the gas mixture was decreased further, the thickness of the modified layers tended to decrease, with $\mathrm{d}_{\mathrm{o}}$ ranging from $(3.3 \pm 0.2) \mu \mathrm{m}$ (treatment atmosphere: 40 vol. $\% \mathrm{~N}_{2}+60$ vol. $\left.\% \mathrm{H}_{2}\right)$ and $(3.2 \pm 0.2) \mu \mathrm{m}\left(40\right.$ vol. $\left.\% \mathrm{~N}_{2}+50 \mathrm{vol} . \% \mathrm{H}_{2}+10 \mathrm{vol} . \% \mathrm{Ar}\right)$ to $(3.0 \pm 0.2) \mu \mathrm{m}\left(20\right.$ vol. $\% \mathrm{~N}_{2}+50$ vol. $\% \mathrm{H}_{2}+30$ vol. $\%$ Ar $)$, and $\mathrm{d}_{\mathrm{i}}$ ranging from $(2.2 \pm 0.2) \mu \mathrm{m}$ (40 vol. $\% \mathrm{~N}_{2}+60$ vol. $\left.\% \mathrm{H}_{2}\right)$ and $(2.1 \pm 0.2) \mu \mathrm{m}\left(40\right.$ vol. $\% \mathrm{~N}_{2}+50$ vol. $\% \mathrm{H}_{2}+10$ vol. $\left.\% \mathrm{Ar}\right)$ to $(1.9 \pm 0.2) \mu \mathrm{m}\left(20 \mathrm{vol} . \% \mathrm{~N}_{2}+50 \mathrm{vol} . \% \mathrm{H}_{2}+30 \mathrm{vol} . \% \mathrm{Ar}\right)$. No significant changes in the microstructure of the layers were observed and many slip lines were observable in the outer modified layer. XRD analysis showed that the peaks of $\gamma_{\mathrm{N}}$ tended to shift towards higher angles as the nitrogen content in the treatment atmosphere decreased (Figure 3b-e), and the asymmetric shape of the peaks was enhanced. In particular, the peak at about $46^{\circ}$, corresponding to the diffraction of the $(200)$ plane in a f.c.c. lattice, resulted as the overlapping of peaks having different interplanar spacings. This fact may be ascribed to the different regions explored by the X-ray beam, having a decreasing nitrogen content and thus different characteristics (lattice expansion [19,38], residual stresses [18,38], lattice defects as stacking faults $[39,40])$, which all contribute to the apparent interplanar spacing. Moreover, the peaks of the $\gamma(\mathrm{N}, \mathrm{C})$ phase, present in the inner modified layer, and those of the austenite substrate, $\gamma$-Fe (f.c.c.), became observable.
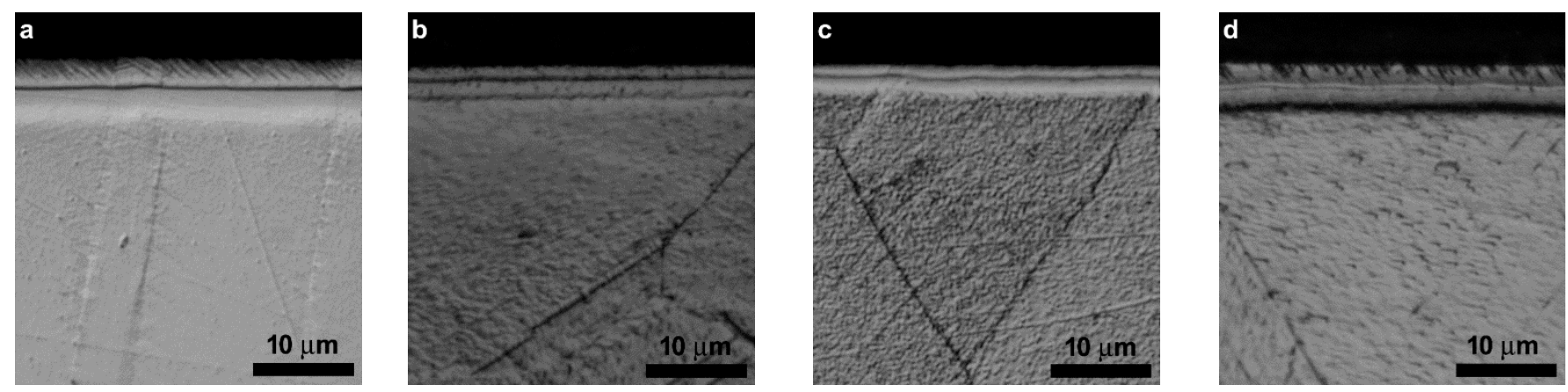

Figure 2. Micrographs of the modified surface layers of samples nitrided at $380{ }^{\circ} \mathrm{C}, 3 \mathrm{~h}, 50 \mathrm{vol} . \% \mathrm{~N}_{2}+50 \mathrm{vol} . \% \mathrm{H}_{2}(\mathbf{a})$, at $360{ }^{\circ} \mathrm{C}, 50 \mathrm{vol} . \% \mathrm{~N}_{2}+50 \mathrm{vol} . \% \mathrm{H}_{2}$, for 1 (b), 3 (c), and 5 (d) h. (Cross-section; etchant: acetic glyceregia).

When nitriding was performed at $360{ }^{\circ} \mathrm{C}$, with a gas mixture of $50 \mathrm{vol} . \% \mathrm{~N}_{2}+50 \mathrm{vol} . \% \mathrm{H}_{2}$, the microstructure of the modified layers depended on treatment duration. Samples nitrided using durations from 1 to $3 \mathrm{~h}$ had an outer modified layer in which shear lines are hardly detectable (Figure 2b,c). When treatment duration was increased up to $5 \mathrm{~h}$, many shear lines were delineated by chemical etching in the outer layer, and the microstructure was comparable to that of $380{ }^{\circ} \mathrm{C}$ nitrided samples (Figure $2 \mathrm{~d}$ ). The thickness of the modified layers increased as the treatment duration was longer, due to nitrogen diffusion, with $\mathrm{d}_{\mathrm{o}}$ ranging from $(1.1 \pm 0.2) \mu \mathrm{m}(\mathrm{t}=1 \mathrm{~h})$ to $(2.3 \pm 0.2) \mu \mathrm{m}(\mathrm{t}=5 \mathrm{~h})$, and $\mathrm{d}_{\mathrm{i}}$ ranging from $(1.3 \pm 0.2) \mu \mathrm{m}(\mathrm{t}=1 \mathrm{~h})$ to $(1.7 \pm 0.2) \mu \mathrm{m}(\mathrm{t}=5 \mathrm{~h})$. In the XRD patterns (Figure 4$)$, the peaks belonging to $\gamma_{\mathrm{N}}$ shifted towards lower angles as treatment duration was longer, suggesting a lattice expansion due to higher nitrogen solubilization, while the peaks of 
$\gamma(\mathrm{N}, \mathrm{C})$ did not shift significantly. As observed for $380^{\circ} \mathrm{C}$ nitrided samples, the asymmetric shape of the $\gamma_{\mathrm{N}}$ peaks was well observable for the diffraction of the (2 00$)$ plane, and for samples treated for $5 \mathrm{~h}$ the $(200)$ peak tended to broaden markedly, with the overlapping of different peaks.

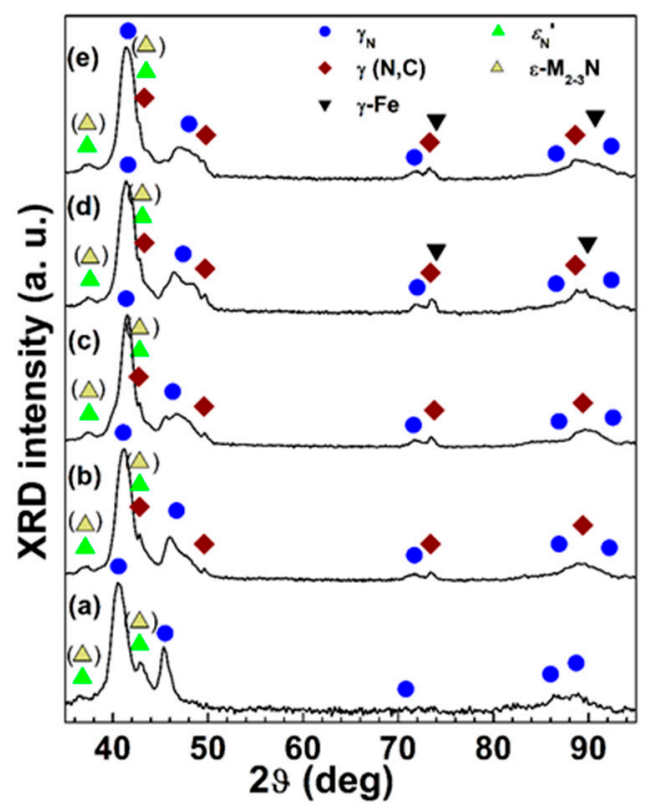

Figure 3. X-ray diffraction patterns of samples nitrided at $380^{\circ} \mathrm{C}$, for $3 \mathrm{~h}$, using the following treatment atmospheres: 50 vol. $\% \mathrm{~N}_{2}+50$ vol. $\% \mathrm{H}_{2}$ (a), 40 vol. $\% \mathrm{~N}_{2}+60$ vol. $\% \mathrm{H}_{2}\left(\right.$ b), 40 vol. $\% \mathrm{~N}_{2}+50$ vol. $\% \mathrm{H}_{2}+$ 10 vol. $\% \operatorname{Ar}\left(\right.$ c), 30 vol. $\% \mathrm{~N}_{2}+50$ vol. $\% \mathrm{H}_{2}+20$ vol. $\% \operatorname{Ar}(\mathbf{d}), 20$ vol. $\% \mathrm{~N}_{2}+50$ vol. $\% \mathrm{H}_{2}+30$ vol. $\% \operatorname{Ar}(\mathbf{e})$.

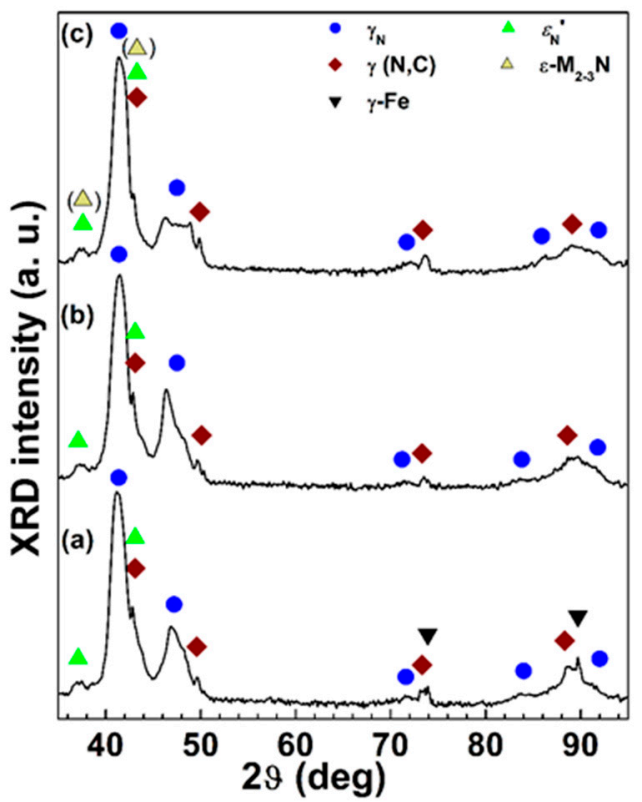

Figure 4. X-ray diffraction patterns of samples nitrided at $360{ }^{\circ} \mathrm{C}$, with 50 vol. $\% \mathrm{~N}_{2}+50$ vol. $\% \mathrm{H}_{2}$, for $1(\mathbf{a}), 3(\mathbf{b})$, and 5 (c) h.

In order to better elucidate the microstructure of the outer modified layer, the surface and tapered sections of the nitrided samples were analyzed. In Figure 5, the surface morphologies of samples nitrided at $360{ }^{\circ} \mathrm{C}$ for 3 and $5 \mathrm{~h}$, and at $380{ }^{\circ} \mathrm{C}$ with 50 vol. $\% \mathrm{~N}_{2}+50$ vol. $\% \mathrm{H}_{2}$ and 20 vol. $\% \mathrm{~N}_{2}+50$ vol. $\% \mathrm{H}_{2}+30$ vol. $\%$ Ar are depicted. All the treated samples showed 
the characteristic surface features previously reported $[15,26,32,33]$. Besides the grooves, due to the grinding and polishing procedures, plasma etching, due to both sputtering and nitriding, delineated the austenitic microstructure. In the samples nitrided at $360{ }^{\circ} \mathrm{C}$ up to $3 \mathrm{~h}$, few grains showed the presence of shear lines (Figure 5a). In the samples nitrided at $360{ }^{\circ} \mathrm{C}$ at $5 \mathrm{~h}$, shear lines were observable in most grains (Figure $5 \mathrm{~b}$ ), as well as in the samples nitrided at $380{ }^{\circ} \mathrm{C}$, irrespectively of the nitrogen content in the treatment atmosphere (Figure $5 \mathrm{c}, \mathrm{d}$ ). Moreover, reliefs were present at grain boundaries and some grain boundaries leaned forward on adjacent grains. Different slip patterns were observable in the grains: besides the typical parallel lines present in the whole grain, quadratic patterns were observed (Figure 5b,d), typical of the intersection of the activated $\left\{\begin{array}{llll}1 & 1 & 1\end{array}\right\}$ slip plane with a $<100>$ oriented crystal, and changes from a parallel pattern to a quadratic one, as that evidenced in the red lined box in Figure $5 b$, were observable, suggesting a rotation of the grain.
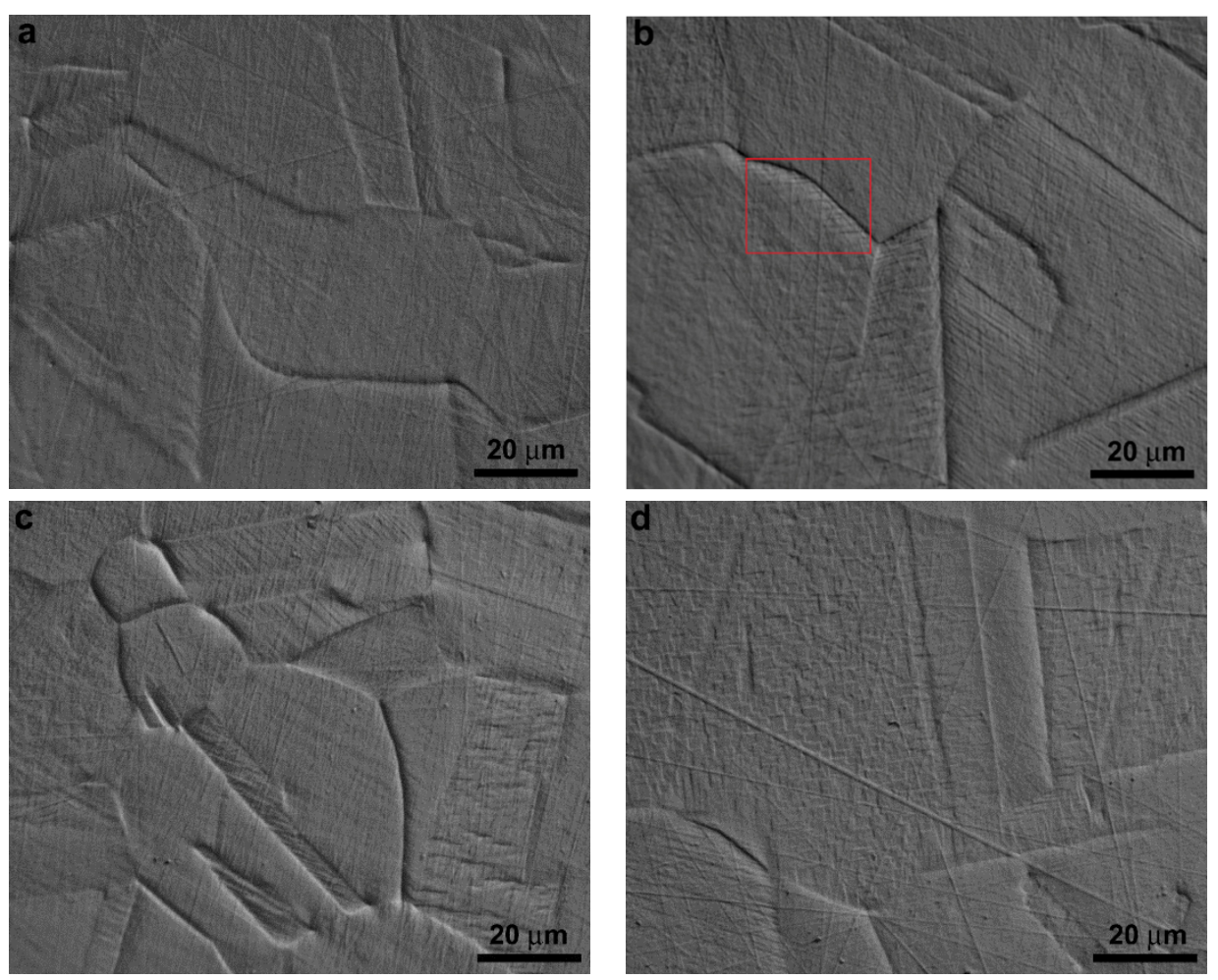

Figure 5. Surface morphology of samples nitrided at $360{ }^{\circ} \mathrm{C}, 50 \mathrm{vol} . \% \mathrm{~N}_{2}+50 \mathrm{vol} . \% \mathrm{H}_{2}$, for 3 (a) and 5 (b) $\mathrm{h}$, and at $380{ }^{\circ} \mathrm{C}, 3 \mathrm{~h}$, with 50 vol. $\% \mathrm{~N}_{2}+50$ vol. $\% \mathrm{H}_{2}$ (c) and 20 vol. $\% \mathrm{~N}_{2}+50$ vol. $\% \mathrm{H}_{2}+30$ vol. $\%$ $\operatorname{Ar}(\mathbf{d})$. The red lined box evidences the change from a parallel pattern of the slip lines to a quadratic one.

The analysis of the tapered sections of the nitrided samples showed that in the samples nitrided at $360{ }^{\circ} \mathrm{C}$ up to $3 \mathrm{~h}$ slip lines were hardly discernible (Figure 6a), while in the samples nitrided for $5 \mathrm{~h}$ or at $380^{\circ} \mathrm{C}$ in the outer part of the modified layers many slip lines were observable in the grains (Figure $6 b$ ). Chemical etching delineated thin lines, which form slip patterns analogous to those observed on the surface (Figure 7). Thin parallel lines were present in the whole grain or in a part of it (Figure 7a,b), but some grains showed the presence of two set of slip lines that crossed, implying that more than one slip system was activated (Figure $7 \mathrm{~b}$ ). Moreover, change in the orientation of slip lines in some grains was observed, as evidenced in the red lined box in Figure 7c. Besides these features, fairly large etched regions suggesting the precipitation of nitrides, as those observed in the $400{ }^{\circ} \mathrm{C}$ nitrided samples, were not observed either along slip lines or along grain boundaries, but the formation of nitrides, having nanometric size, along the slip lines cannot be excluded. 

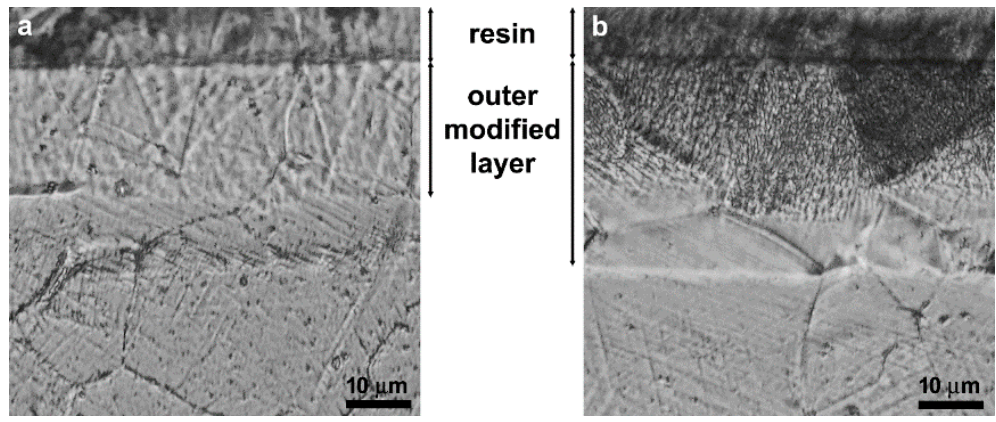

Figure 6. Micrographs of samples nitrided with 50 vol. $\% \mathrm{~N}_{2}+50$ vol. $\% \mathrm{H}_{2}$, for $3 \mathrm{~h}$, at 360 (a) and 380 (b) ${ }^{\circ} \mathrm{C}$. (Tapered section: the markers refer to the length in the tapered section; etchant: glyceregia).
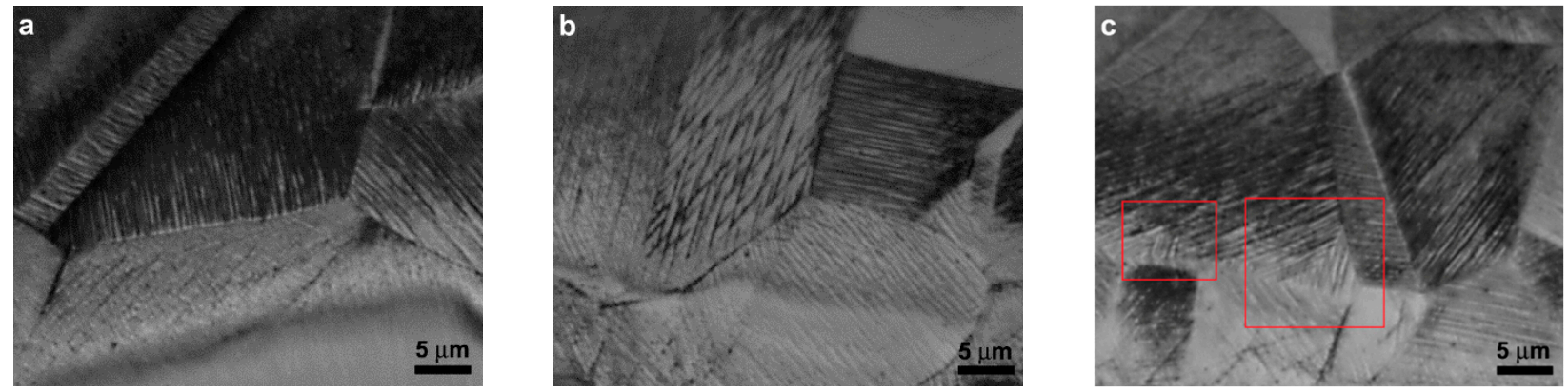

Figure 7. Details (parallel slip lines (a), crossing slip lines (b), slip lines changing their orientation (c)) of the microstructure of the outer modified surface layer of a sample nitrided at $380{ }^{\circ} \mathrm{C}, 3 \mathrm{~h}, 50 \mathrm{vol} . \% \mathrm{~N}_{2}+50 \mathrm{vol} . \% \mathrm{H}_{2}$. The red lined boxes in (c) evidence the change in orientation of the slip lines. (Tapered section: the markers refer to the length in the tapered section; etchant: acetic glyceregia).

\subsection{Surface Microhardness}

Surface microhardness values of untreated and nitrided samples are shown in Figure 8. All the treatments allowed to increase surface hardness, in comparison with the untreated alloy. When a $10 \mathrm{~g}_{\mathrm{f}}$ load was used, microhardness values of samples nitrided at 360 and $380{ }^{\circ} \mathrm{C}$ were affected by both the hard nitrogen-rich $\gamma_{\mathrm{N}}$ in the upmost layer and strain hardening effects due to localized plastic deformations. As the load was higher, lower microhardness values were detected, due to both the indentation size effect and the fact that layers with different characteristics were tested.

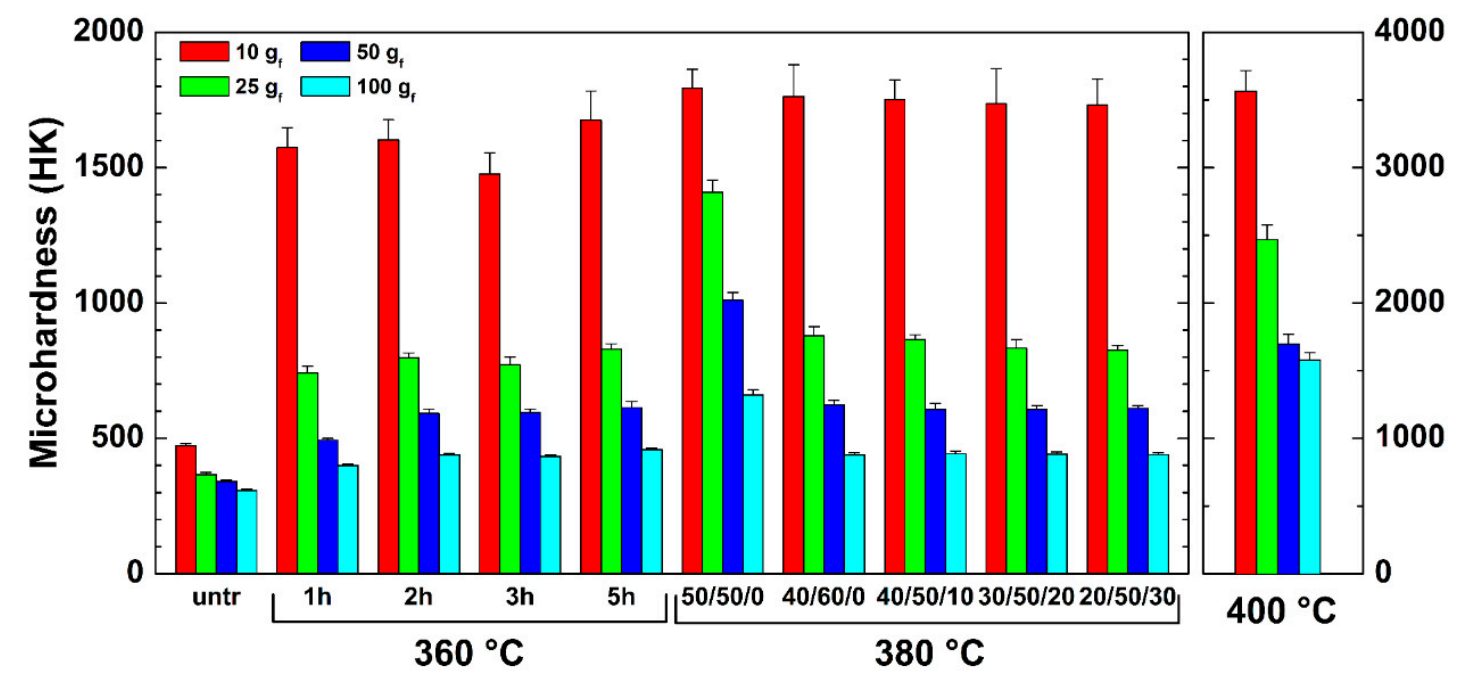

Figure 8. Surface Knoop microhardness values of samples untreated and nitrided as indicated. (For sample type, refer to Table 1). 
For samples nitrided at $400{ }^{\circ} \mathrm{C}$, microhardness values as high as about $3500 \mathrm{HK}_{0.01}$ were detected, due to the precipitation of a large volume fraction of very hard nitrides.

\subsection{Corrosion Behavior}

\subsubsection{Electrochemical Impedance Spectroscopy Analysis}

Typical EIS spectra of samples untreated and nitrided at $360{ }^{\circ} \mathrm{C}(3 \mathrm{~h}), 380{ }^{\circ} \mathrm{C}$ (50 vol. $\% \mathrm{~N}_{2}+50$ vol. $\% \mathrm{H}_{2}$ ), and $400{ }^{\circ} \mathrm{C}$, tested at the respective OCPs, are depicted in Figure 9 in form of Bode plots. While the samples nitrided at 360 and $380{ }^{\circ} \mathrm{C}$ had higher impedance values than those of the untreated steel, for samples nitrided at $400{ }^{\circ} \mathrm{C}$, impedance values were significantly lower, suggesting a decrease of corrosion resistance.

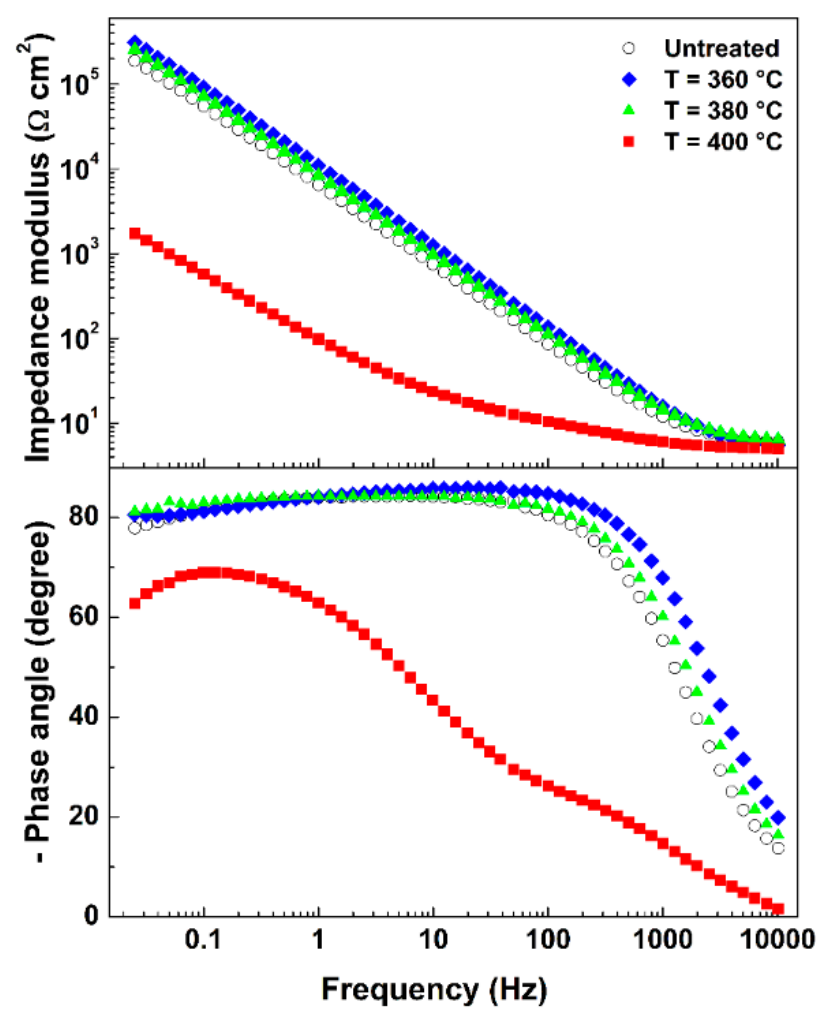

Figure 9. Bode plots of samples untreated, nitrided for $3 \mathrm{~h}$, at 360 and $380{ }^{\circ} \mathrm{C}$, using 50 vol. $\% \mathrm{~N}_{2}+50$ vol. $\% \mathrm{H}_{2}$, and at $400{ }^{\circ} \mathrm{C}$, using 80 vol. $\% \mathrm{~N}_{2}+20$ vol. $\% \mathrm{H}_{2}$.

Representative EIS spectra of samples nitrided at $360^{\circ} \mathrm{C}$ for different durations and at $380^{\circ} \mathrm{C}$ with different nitrogen content in the treatment atmosphere are shown in Figure 10. For all the tested treatment conditions, the impedance values were comparable or higher than those of the untreated alloy, so that it may be hypothesized that the corrosion resistance of the steel was maintained or even increased. A physical picture of the corrosion behavior can be obtained modelling the experimental data with an equivalent electrical circuit (EEC). The used EECs are represented in the insets of Figure 10, and the corresponding EEC parameter values, obtained fitting experimental data, are reported in Tables 2 and 3. 

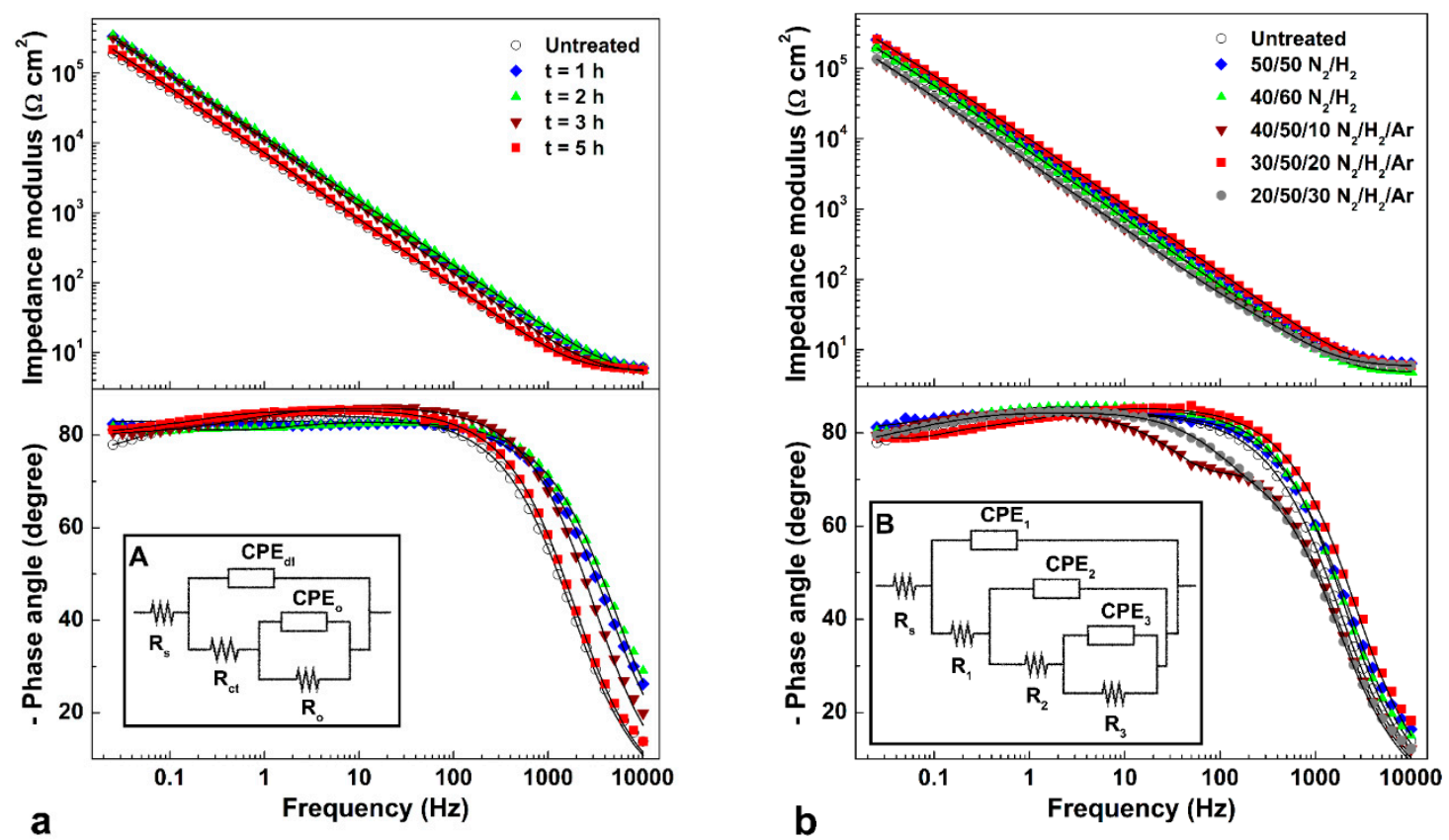

Figure 10. Bode plots of samples untreated, and nitrided at 360 (a) and $380(\mathbf{b}){ }^{\circ} \mathrm{C}$ as indicated, recorded at the respective OCP values. Symbols: experimental data; lines: modelled data obtained using the equivalent electrical circuits depicted in insets $\mathrm{A}$ and $\mathrm{B}$ as explained in the text.

Table 2. Best fitting EEC parameter values for EIS spectra of samples untreated and nitrided at $360{ }^{\circ} \mathrm{C}$ for different durations, tested at the respective OCP (model: inset A in Figure 10a). EEC: equivalent electrical circuit. EIS: electrochemical impedance spectroscopy. OCP: open circuit potential. Rct: charge transfer resistance. CPEdl: double layer/space charge capacitance. CPE: constant phase elements.

\begin{tabular}{|c|c|c|c|c|c|c|c|c|c|}
\hline Sample Type & $\begin{array}{l}\text { OCP } \\
(\mathrm{mV})\end{array}$ & $\begin{array}{c}R_{\mathrm{s}} \\
\left(\Omega \mathrm{cm}^{2}\right)\end{array}$ & $\begin{array}{c}R_{\mathrm{ct}} \\
\left(\mathrm{M} \Omega \mathrm{cm}^{2}\right)\end{array}$ & $\begin{array}{c}\mathrm{CPE}_{\mathrm{dl}} \times 10^{5} \\
\left(\Omega^{-1} \mathrm{~s}^{\mathrm{n}} \mathrm{cm}^{-2}\right)\end{array}$ & $n_{\mathrm{dl}}$ & $\begin{array}{c}\mathrm{R}_{\mathrm{o}} \\
\left(\mathrm{M} \Omega \mathrm{cm}^{2}\right)\end{array}$ & $\begin{array}{c}C P E_{o} \times 10^{5} \\
\left(\Omega^{-1} s^{n} c^{-2}\right)\end{array}$ & $n_{\mathrm{o}}$ & $\begin{array}{c}R_{\text {tot }} \\
\left(\mathrm{M} \Omega \mathrm{cm}^{2}\right)\end{array}$ \\
\hline untreated & $-44 \pm 10$ & $5.8 \pm 0.1$ & $0.9 \pm 0.2$ & $2.8 \pm 0.1$ & $0.94 \pm 0.01$ & $2.9 \pm 0.5$ & $0.81 \pm 0.06$ & $0.90 \pm 0.03$ & $3.8 \pm 0.7$ \\
\hline nitr- $-1 \mathrm{~h}$ & $+238 \pm 10$ & $5.0 \pm 0.1$ & $2.2 \pm 0.1$ & $1.6 \pm 0.1$ & $0.92 \pm 0.01$ & $415 \pm 80$ & $0.10 \pm 0.06$ & $0.99 \pm 0.01$ & $417 \pm 80$ \\
\hline nitr. $-2 \mathrm{~h}$ & $+239 \pm 10$ & $4.6 \pm 0.1$ & $0.8 \pm 0.2$ & $1.5 \pm 0.1$ & $0.92 \pm 0.01$ & $328 \pm 80$ & $0.16 \pm 0.02$ & $0.96 \pm 0.02$ & $329 \pm 80$ \\
\hline nitr.-3h & $+218 \pm 10$ & $5.1 \pm 0.1$ & $0.5 \pm 0.1$ & $2.1 \pm 0.1$ & $0.95 \pm 0.01$ & $189 \pm 60$ & $0.48 \pm 0.09$ & $0.86 \pm 0.03$ & $190 \pm 60$ \\
\hline nitr. $-5 \mathrm{~h}$ & $+166 \pm 10$ & $5.4 \pm 0.1$ & $0.4 \pm 0.1$ & $2.4 \pm 0.1$ & $0.95 \pm 0.01$ & $139 \pm 60$ & $0.25 \pm 0.02$ & $0.68 \pm 0.02$ & $139 \pm 60$ \\
\hline
\end{tabular}

Table 3. Best fitting EEC parameter values for EIS spectra of samples nitrided at $380^{\circ} \mathrm{C}$ with different treatment atmospheres (indicated as ratio of the volume percent of $\mathrm{N}_{2}$ to $\mathrm{H}_{2}$ to Ar content), tested at the respective OCP (model: inset B in Figure 10b).

\begin{tabular}{|c|c|c|c|c|c|c|c|c|c|c|c|c|}
\hline $\begin{array}{l}\text { Sample } \\
\text { Type }\end{array}$ & $\begin{array}{l}\text { OCP } \\
(\mathrm{mV})\end{array}$ & $\begin{array}{c}R_{\mathrm{S}} \\
\left(\Omega \mathrm{cm}^{2}\right)\end{array}$ & $\begin{array}{c}R_{1} \\
\left(k \Omega \mathrm{cm}^{2}\right)\end{array}$ & $\begin{array}{c}\mathrm{CPE}_{1} \times 10^{5} \\
\left(\Omega^{-1} \mathrm{~s}^{\mathrm{n}} \mathrm{cm}^{-2}\right)\end{array}$ & $n_{1}$ & $\begin{array}{c}\mathrm{R}_{2} \\
\left(\mathrm{M} \Omega \mathrm{cm}^{2}\right)\end{array}$ & $\begin{array}{c}\mathrm{CPE}_{2} \times 10^{5} \\
\left(\Omega^{-1} \mathrm{~s}^{\mathrm{n}} \mathrm{cm}^{-2}\right)\end{array}$ & $n_{2}$ & $\begin{array}{c}R_{3} \\
\left(\mathrm{M} \Omega \mathrm{cm}^{2}\right)\end{array}$ & $\begin{array}{c}\mathrm{CPE}_{3} \times 10^{5} \\
\left(\Omega^{-1} \mathrm{~s}^{\mathrm{n}} \mathrm{cm}^{-2}\right)\end{array}$ & $n_{3}$ & $\begin{array}{c}\mathbf{R}_{\text {tot }} \\
\left(\mathrm{M} \Omega \mathrm{cm}^{2}\right)\end{array}$ \\
\hline $50 / 50 / 0$ & $+210 \pm 10$ & $5.5 \pm 0.1$ & $1.3 \pm 0.3$ & $2.0 \pm 0.2$ & $0.94 \pm 0.01$ & $1.9 \pm 0.3$ & $0.8 \pm 0.1$ & $0.81 \pm 0.03$ & $260 \pm 70$ & $0.7 \pm 0.3$ & $0.77 \pm 0.06$ & $262 \pm 70$ \\
\hline $40 / 60 / 0$ & $+195 \pm 10$ & $4.6 \pm 0.1$ & $4.5 \pm 0.3$ & $2.6 \pm 0.1$ & $0.96 \pm 0.01$ & $0.6 \pm 0.1$ & $0.04 \pm 0.01$ & $0.80 \pm 0.03$ & $137 \pm 60$ & $0.47 \pm 0.02$ & $0.84 \pm 0.02$ & $138 \pm 60$ \\
\hline $40 / 50 / 10$ & $+179 \pm 10$ & $5.8 \pm 0.1$ & $0.4 \pm 0.1$ & $3.4 \pm 0.1$ & $0.92 \pm 0.01$ & $1.3 \pm 0.2$ & $0.72 \pm 0.06$ & $0.99 \pm 0.01$ & $237 \pm 70$ & $0.39 \pm 0.06$ & $0.87 \pm 0.05$ & $238 \pm 70$ \\
\hline $30 / 50 / 20$ & $+196 \pm 10$ & $5.5 \pm 0.1$ & $95 \pm 4$ & $1.7 \pm 0.1$ & $0.96 \pm 0.01$ & $1.2 \pm 0.2$ & $0.30 \pm 0.02$ & $0.77 \pm 0.03$ & $134 \pm 60$ & $0.25 \pm 0.02$ & $0.86 \pm 0.05$ & $135 \pm 60$ \\
\hline $20 / 50 / 30$ & $+188 \pm 10$ & $5.7 \pm 0.1$ & $0.2 \pm 0.1$ & $3.4 \pm 0.1$ & $0.93 \pm 0.01$ & $0.7 \pm 0.1$ & $0.45 \pm 0.02$ & $0.99 \pm 0.01$ & $258 \pm 70$ & $0.67 \pm 0.05$ & $0.83 \pm 0.05$ & $259 \pm 70$ \\
\hline
\end{tabular}

For the samples untreated and nitrided at $360^{\circ} \mathrm{C}$ (Figure 10a), an EEC with two time constants was used (inset A), taking into account the asymmetry of the phase angle plots, and the corresponding EEC parameter values are reported in Table 2. A similar EEC was used for modelling EIS spectra of austenitic stainless steels untreated or subjected to different surface treatments [26,41-43]. The high-frequency (HF) time constant is related to the charging/discharging processes occurring at the electrode/electrolyte interface, and the low frequency (LF) time constant to the processes occurring in the oxide phase. The meanings of the electronic elements are as follows: $R_{S}$ is the electrolyte resistance, 
for the HF time constant, $R_{c t}$ is the charge transfer resistance and $C P E_{d l}$ is the double layer/space charge capacitance, for the LF time constant, $R_{o}$ and $C P E_{o}$ take into account mass transport and charge transfer processes occurring in the oxide. The sum of $R_{c t}$ and $R_{O}$ can be considered a measure of the surface total resistance to general corrosion [41]. The use of constant phase elements (CPE), instead of pure capacitances, allows to take into account the distribution of relaxation times due to inhomogeneities as surface roughness/porosity, adsorption, and diffusion [43]. The impedance of CPE is defined as:

$$
\mathrm{Z}=[\mathrm{CPE}(\mathrm{i} \omega) \mathrm{n}]-1
$$

where CPE is a constant parameter, $\omega$ is the angular frequency, $i^{2}=-1$ is the imaginary number, and $n$ is the CPE exponent.

The analysis of EIS data showed that, for the $360{ }^{\circ} \mathrm{C}$ nitrided samples, $\mathrm{R}_{\mathrm{O}}$, and then $\mathrm{R}_{\text {tot, }}$ were markedly higher than that of the untreated alloy, so that a better corrosion resistance was expected. However, as the treatment duration increased, $R_{O}$ tended to decrease, and the same trend was observed for $n_{0}$. The deviation from a pure capacitance behavior $(n=1)$ of the oxide layer may be ascribed to surface heterogeneities, variation of the oxide composition, and diffusion phenomena in the oxide film [44].

When the EIS spectra of $380{ }^{\circ} \mathrm{C}$ nitrided samples were analyzed, the asymmetry of the phase angle plots become more complex, with the presence of three slight inflections in the curve. As a consequence, a model with three time constants hierarchically connected was used (inset B of Figure 10b) and the corresponding EEC parameter values are reported in Table 3. Taking into account similar models, proposed for inhomogeneous surfaces $[45,46]$, and our previous study [26], it may be hypothesized that $\mathrm{R}_{1}$ and $C P E_{1}$ are related with a porous and/or heterogeneous oxide layer, $\mathrm{R}_{2}$ and $\mathrm{CPE}_{2}$ with the processes occurring at the electrode/electrolyte interface, and $\mathrm{R}_{3}$ and $\mathrm{CPE}_{3}$ with the processes occurring in the inner compact oxide phase. For all the nitrided samples, $R_{\text {tot }}$ values were significantly higher than that of the untreated steel, suggesting a better corrosion resistance.

\subsubsection{Potentiodynamic Analysis}

Typical polarization curves of samples untreated and nitrided at $360{ }^{\circ} \mathrm{C}(3 \mathrm{~h}), 380{ }^{\circ} \mathrm{C}$ (50 vol. $\% \mathrm{~N}_{2}+50$ vol. $\% \mathrm{H}_{2}$ ), and $400{ }^{\circ} \mathrm{C}$ are depicted in Figure 11 . For the samples untreated and nitrided at 360 and $380{ }^{\circ} \mathrm{C}$, the polarization curves were typical of passive materials, with low anodic current densities. The samples nitrided at $400{ }^{\circ} \mathrm{C}$ had significantly lower potential values and higher anodic current densities in comparison with those of the untreated alloy. This poor corrosion resistance can be ascribed to the precipitation of a large amount of nitrides, which hindered repassivation of the oxide film when corrosion phenomena occurred.

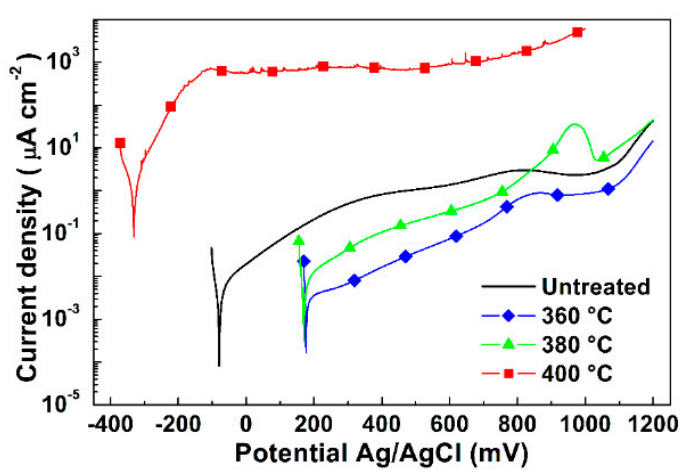

Figure 11. Polarization curves of samples untreated, nitrided for $3 \mathrm{~h}$, at 360 and $380{ }^{\circ} \mathrm{C}$, using 50 vol. $\% \mathrm{~N}_{2}+50$ vol. $\% \mathrm{H}_{2}$, and at $400{ }^{\circ} \mathrm{C}$, using 80 vol. $\% \mathrm{~N}_{2}+20$ vol. $\% \mathrm{H}_{2}$.

Typical polarization curves of samples nitrided at $360^{\circ} \mathrm{C}$ for different durations and at $380{ }^{\circ} \mathrm{C}$ with different nitrogen content in the treatment atmosphere are shown in Figure 12. 
All the samples nitrided at 360 and $380^{\circ} \mathrm{C}$ had a significantly higher corrosion potential, in comparison with that of the untreated steel. Regarding anodic current density values, for the samples nitrided at $360^{\circ} \mathrm{C}$ up to $3 \mathrm{~h}$ they were significantly lower than those of the untreated alloy for all the scanned voltage range. For the samples nitrided at $360{ }^{\circ} \mathrm{C}$ for $5 \mathrm{~h}$ and for all those treated at $380^{\circ} \mathrm{C}$, anodic current density values were fairly low up to about $+630 \mathrm{mV}(\mathrm{Ag} / \mathrm{AgCl})$, then they had a fast increase up to about $+960 \mathrm{mV}(\mathrm{Ag} / \mathrm{AgCl})$ and then decreased.
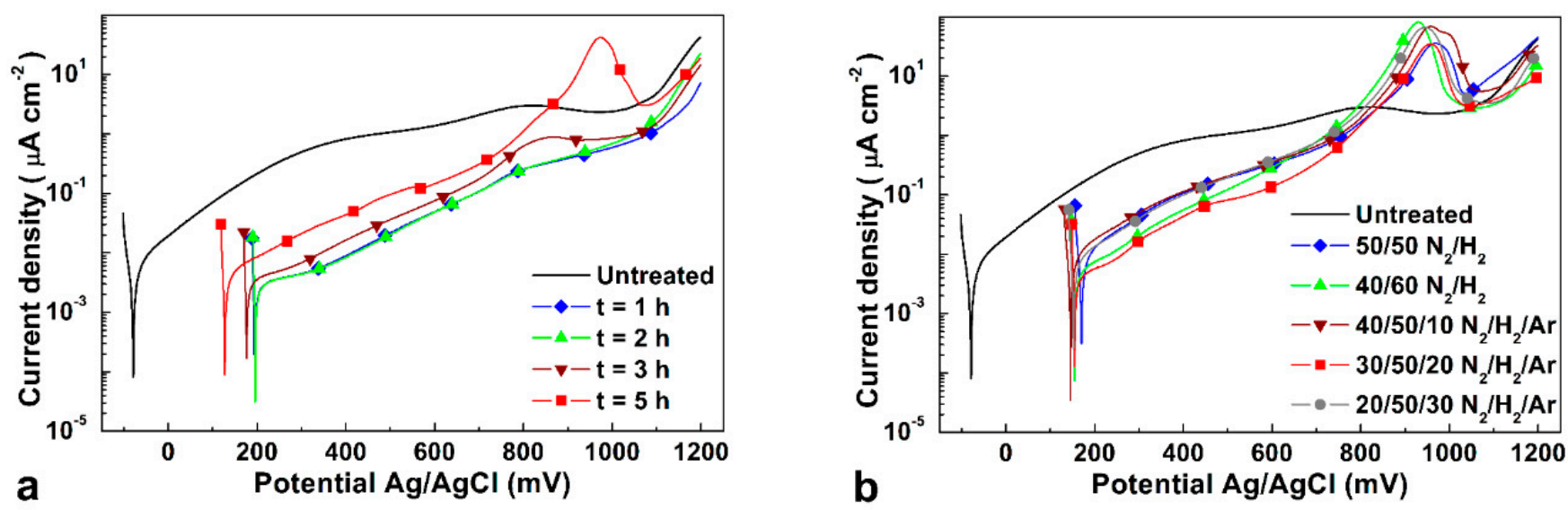

Figure 12. Polarization curves of samples untreated, and nitrided at $360(\mathbf{a})$ and $380(\mathbf{b}){ }^{\circ} \mathrm{C}$ as indicated.

After the tests, on the surface of the untreated samples, a thin groove in the area shielded by the PTFE gasket was observable, due to crevice phenomena (Figure 13a). Microscopy analysis showed also the presence of some fairly deep micrometric pits (Figure 14a). For the samples nitrided at $360^{\circ} \mathrm{C}$ up to $3 \mathrm{~h}$, the surface seemed fairly untouched, with only minor traces of corrosion phenomena due to crevice (Figure 13b). Few micrometric and submicrometric pits were present (Figure 14b). After the test, the surfaces of the samples nitrided at $360{ }^{\circ} \mathrm{C}$ for $5 \mathrm{~h}$ and at $380^{\circ} \mathrm{C}$ had a similar appearance (Figure 13c,d). In part of the surface shielded by the gasket a strong coloring occurred, while the other part of the surface was affected only by minor corrosion phenomena, with very few shallow pits observable on selected samples. Microscopy analysis showed that this coloring tended to be present along the grinding grooves, which may act as micro-crevices and that small pits tended to develop in these regions (Figure 14c-e). Micrometric and submicrometric pits were observable, and they tended to develop also on grain boundaries and shear lines (Figure 14f).
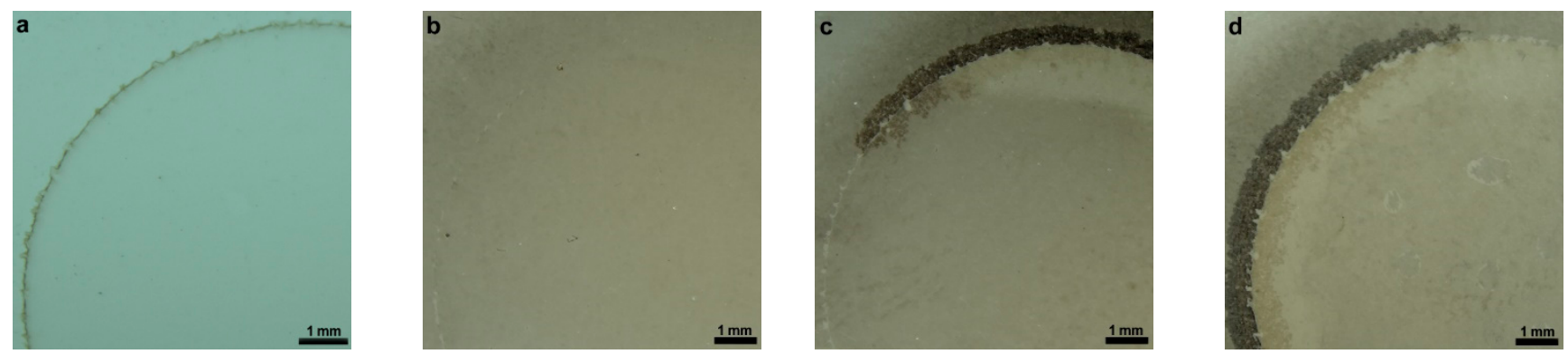

Figure 13. Surface morphology (detail) after the potentiodynamic tests of samples untreated (a), nitrided at $360{ }^{\circ} \mathrm{C}$, 50 vol. $\% \mathrm{~N}_{2}+50$ vol. $\% \mathrm{H}_{2}$, for $1\left(\right.$ b) and 5 (c) $\mathrm{h}$, and at $380{ }^{\circ} \mathrm{C}, 50$ vol. $\% \mathrm{~N}_{2}+50$ vol. $\% \mathrm{H}_{2}$, for $3 \mathrm{~h}$ (d). 

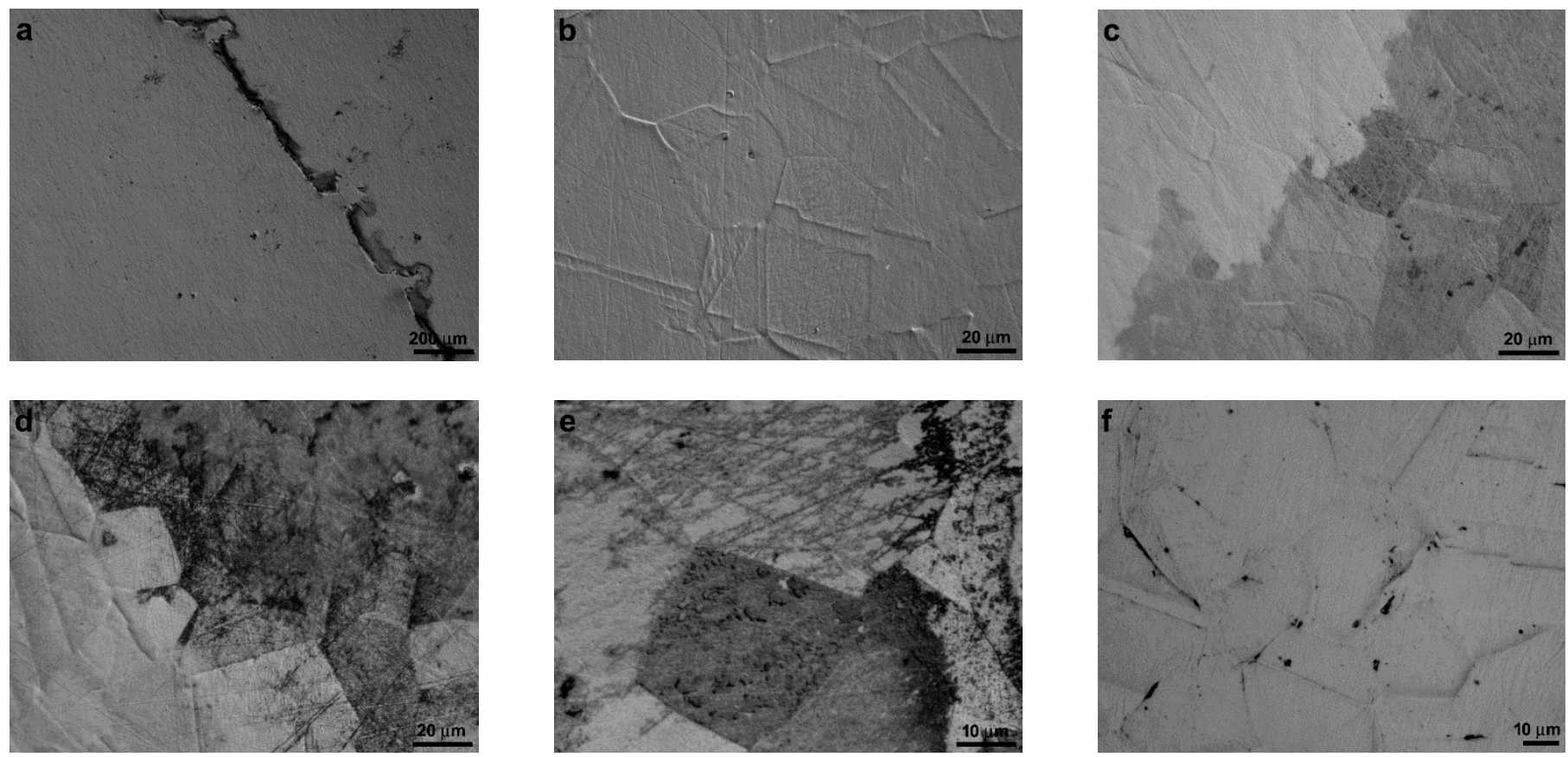

Figure 14. Micrographs of the surface morphology after the potentiodynamic tests of samples untreated (a), nitrided at $360{ }^{\circ} \mathrm{C}, 50$ vol. $\% \mathrm{~N}_{2}+50$ vol. $\% \mathrm{H}_{2}$, for 1 (b) and 5 (c) $\mathrm{h}$, and at $380{ }^{\circ} \mathrm{C}, 50 \mathrm{vol} . \% \mathrm{~N}_{2}+50$ vol. $\% \mathrm{H}_{2}$, for $3 \mathrm{~h}(\mathbf{d}-\mathbf{f})$.

\section{Discussion}

Low-temperature nitriding is an effective method for increasing surface hardness of austenitic stainless steels, maintaining or even improving their corrosion resistance. As reported in our previous papers [27,36] and by other authors $[28,47,48]$, the choice of treatment parameters is strictly connected with the steel composition in order to avoid the precipitation of large amounts of nitrides, which are able to improve surface hardness, but cause a worsening of corrosion resistance. High manganese-containing austenitic stainless steels, as AISI 200 series and Ni-free steels, are particularly sensitive to treatment conditions. As shown by Buhagiar [31] and Buhagiar et al. [28], and confirmed in this study, treatment conditions, which allow to produce nitride-free modified surface layers in AISI 300 series austenitic stainless steels, may be not suitable to avoid nitride precipitation in a Ni-free stainless steel. In fact, for the Ni-free steel studied in this research, the use of a $400{ }^{\circ} \mathrm{C}$ treatment temperature, which was lower than $430^{\circ} \mathrm{C}$, employed by Buhagiar [31] and Buhagiar et al. [28], and allowed to produce nitride-free layers in AISI 316L [27], caused the formation of a fairly large amount of nitrides, which markedly increased surface microhardness, but produced a significant worsening of corrosion resistance in $5 \% \mathrm{NaCl}$ solution. On the other hand, the investigated treatment conditions $\left(360\right.$ and $380^{\circ} \mathrm{C}, 50$ vol. $\%$ $\mathrm{N}_{2}$ in the gas mixture or lower, durations up to $5 \mathrm{~h}$ ) seem able to avoid the precipitation of large amounts of nitrides and allow the formation of modified surface layers consisting mainly of $\gamma_{\mathrm{N}}$. This fact can be ascribed to the peculiar conditions of low-temperature treatments. As recalled also in the introduction, the diffusion of interstitial atoms is faster than that of substitutional atoms, so that at low temperatures nitrogen atoms can freely diffuse while substitutional atoms have a much slower diffusion and they can be considered relatively "immobile" in the lattice [16-18]. As a consequence, chromium, which has a stronger affinity for nitrogen in comparison with iron, is hindered in forming nitrides. In the CrNi AISI 300 series stainless steels, the presence of nickel, which does not form nitrides, favors the formation of a nitride-free $\gamma_{\mathrm{N}}$ layer up to about $450{ }^{\circ} \mathrm{C}$. The substitution of nickel, in whole or in part, with manganese introduces an additional nitride forming element in the lattice. Thus, in order to avoid nitride precipitation, the diffusion of substitutional atoms should be decreased further by decreasing the treatment temperature and using fairly short 
treatment durations. It may be hypothesized that, when longer nitriding durations are used, a significant volume fraction of nitrides can be produced in the studied Ni-free steel also at 360 and $380{ }^{\circ} \mathrm{C}$, since for low-temperature treatments nitride precipitation is both a chemical and diffusion driven process [18,23].

The modified surface layers microstructure obtained in the samples nitrided at 360 and $380{ }^{\circ} \mathrm{C}$ had the typical two-layer microstructure observed in both AISI 300 and AISI 200 series stainless steels [15,27,36,49]. Nitrogen solubilization well beyond solubility limit in the austenite lattice caused a large lattice expansion, as observed by the shifting towards lower angles of austenite peaks in XRD patterns. As a consequence, localized plastic deformations occurred, which can be inferred by the shear bands observable in the cross-section of the samples and at the surface, and by the reliefs present at grain boundaries, due to a swelling of the grains [50]. Large plastic deformations were well observable only for samples nitrided at $360{ }^{\circ} \mathrm{C}$ with longer treatment durations (5 h), and for those treated at $380^{\circ} \mathrm{C}$, irrespective of the nitrogen content in the treatment atmosphere, so that it may be hypothesized that the fairly high yield strength of Ni-free steel [8] tends to delay these phenomena. Local plastic deformations are strictly related also to the formation of nitrogen-induced h.c.p. $\varepsilon_{\mathrm{N}}{ }^{\prime}$ martensite. In fact, when plastic deformations occur in austenitic stainless steels, the fairly low stacking fault energy of these alloys, decreased further on by nitrogen solubilization [51], may allow the formation of wide stacking faults, having the characteristic ABAB stacking of a h.c.p. structure [52]. The formation of this h.c.p. phase together with $\gamma_{\mathrm{N}}$ was reported by many authors $[26,27,36,37,47,49,53]$, and it was higher in manganese-containing austenitic stainless steels than in CrNi-based ones $[26,27,36,54]$, since manganese up to about $14 \mathrm{wt} . \%$ tends to decrease the stacking fault energy [55]. According to Tong et al. [39], these h.c.p. regions should be regarded as "clustered" stacking faults, instead of thin plates of nitrogen-rich, h.c.p. martensite. On the contrary, for Lei et al. [35] this h.c.p. structure may be considered equivalent to the $\varepsilon^{\prime}$ martensite formed as a consequence of plastic deformations, and having larger lattice parameters due to nitrogen solubilization. According to Tao et al. [53], $\varepsilon_{\mathrm{N}}{ }^{\prime}$ forms from $\gamma_{\mathrm{N}}$, and not from an unexpanded $\varepsilon^{\prime}$, through a martensitic shear transformation above a critical nitrogen concentration. When the $\varepsilon_{\mathrm{N}}{ }^{\prime}$ phase formed in a large amount, the transformation of $\varepsilon_{\mathrm{N}}{ }^{\prime}$ into the h.c.p. $\varepsilon$ nitride cannot completely ruled out, even if the characteristic peaks due to the ordering of nitrogen atoms were not observed in the XRD patterns.

The surface microhardness increase observed for the 360 and $380^{\circ} \mathrm{C}$ nitrided samples, in comparison with the untreated alloy, was due to both solid solution strengthening and a strain hardening effect. The hardening effect was particularly appreciable using a $10 \mathrm{~g}_{\mathrm{f}}$ indenter load, which allowed to evaluate the upmost layers. Using higher indenter loads, a deeper indentation was produced, so that microhardness values were influenced by the characteristics of the modified layers, which change with depth (interstitial atom content, strain hardening, residual stress), and of the substrate. Higher values were detected as the modified layers are thicker. Nitride precipitation, as in the samples nitrided at $400{ }^{\circ} \mathrm{C}$, was able to increase surface microhardness further on, and values exceeding those typical of $\gamma_{\mathrm{N}}$ were obtained.

The treatment conditions influenced also the corrosion behavior in $5 \% \mathrm{NaCl}$. As previously reported $[13,15,23,56]$, the precipitation of a large volume fraction of nitrides, as in the $400{ }^{\circ} \mathrm{C}$ nitrided samples, prevented the matrix to form a protective passive layer, promoting localized corrosion phenomena. On the other hand, for the samples nitrided at 360 and $380{ }^{\circ} \mathrm{C}$ nitrogen solubilization allowed to promote a higher corrosion resistance, as compared to that of the untreated steel, as put in evidence by EIS analysis. A significant increase of corrosion potential values was observed, and anodic currents in the passive branch tended to decrease. A peculiar behavior was observed in the samples nitrided at $360^{\circ} \mathrm{C}$ for $5 \mathrm{~h}$ and at $380{ }^{\circ} \mathrm{C}$, irrespectively of the nitrogen content in the treatment atmosphere, subjected to polarization tests. Even if these sample types had a high corrosion potential, they were subjected to localized corrosion phenomena, which produced a larger damage in comparison with that observed for the samples nitrided at $360{ }^{\circ} \mathrm{C}$ up to $3 \mathrm{~h}$. 
The analysis of the anodic current density trend showed that it tended to increase from about $+630 \mathrm{mV}(\mathrm{Ag} / \mathrm{AgCl})$, it reached a maximum at about $+960 \mathrm{mV}(\mathrm{Ag} / \mathrm{AgCl})$, and then it decreased to values of a second passivity branch, suggesting that oxidation phenomena occurred. As observed previously [26], on the basis of the Pourbaix diagram for a Cr-MnMo steel [57], for an acidic solution, as expected for crevice or pitting, the oxidation of $\mathrm{Cr}^{3+}$ to $\mathrm{Cr}^{+6}$ may be supposed. At these potentials, $\mathrm{MoO}_{3}$ may also transform into soluble $\mathrm{MoO}_{4}{ }^{2-}$, while at higher potentials manganese may contribute with the oxidation of $\mathrm{Mn}^{4+}$ to $\mathrm{Mn}^{7+}$. A similar anodic current peak, more or less high, was observed for untreated austenitic stainless steels, the $22 \mathrm{Cr}-18 \mathrm{Mn}-0.83 \mathrm{~N}$ Ni-free austenitic stainless steel subjected to different rolling strains [58] and the superaustenitic UNS S31254 (20Cr-18Ni-7Mo-0.2N) stainless steel [59], and for nitrided AISI 202 [27,36], AISI 316L [27], and AISI 304L [36] stainless steels tested in $\mathrm{NaCl}$ solutions. Taking into account the composition of these steels, it may be hypothesized that chromium oxidation played a major role. It may be supposed that these corrosion phenomena were promoted by the heterogeneous structure formed by $\gamma_{\mathrm{N}}$ and a fairly large amount of h.c.p. phase $\left(\varepsilon_{\mathrm{N}}{ }^{\prime}\right.$ and/or nitride precipitates), typical of these sample types, which might hinder repassivation when corrosion occurred.

\section{Conclusions}

Low-temperature nitriding can be applied successfully to austenitic stainless steels having a high manganese content and a negligible nickel one, as the so-called Ni-free stainless steels. Due to the substitution of nickel with manganese, which is a nitride forming element, this steel type is more sensitive to nitride precipitation than AISI 316L, but operating at temperatures lower than $400{ }^{\circ} \mathrm{C}$ and using fairly short treatment durations it is possible to obtain modified surface layers consisting mainly of expanded austenite, $\gamma_{\mathrm{N}}$, and avoid the formation of a large volume fraction of nitride precipitates.

With the treatment parameters used in the present study $\left(360\right.$ and $380{ }^{\circ} \mathrm{C}, 50 \mathrm{vol} . \% \mathrm{~N}_{2}$ in the gas mixture or lower, durations up to $5 \mathrm{~h}$ ), the modified surface layers consisted of an outer layer, in which $\gamma_{\mathrm{N}}$ was present together with nitrogen-rich h.c.p. martensite, $\varepsilon_{\mathrm{N}}{ }^{\prime}$, and an inner layer, consisting of a solid solution of interstitial atoms in the slightly expanded austenite lattice, $\gamma(\mathrm{N}, \mathrm{C})$. Shear bands, due to localized plastic deformations occurring when the modified layers formed, were observable at the surface and in the cross-section of the outer modified layer, in particular on samples nitrided at $360{ }^{\circ} \mathrm{C}$ for $5 \mathrm{~h}$ and at $380{ }^{\circ} \mathrm{C}$.

For all the nitrided samples, surface microhardness increased if compared to the untreated steel, owing to solid solution strengthening and strain hardening effects.

Corrosion resistance in $5 \% \mathrm{NaCl}$ was significantly improved for the samples nitrided at $360{ }^{\circ} \mathrm{C}$ up to $3 \mathrm{~h}$. When the samples were treated at $360^{\circ} \mathrm{C}$ for $5 \mathrm{~h}$ and at $380{ }^{\circ} \mathrm{C}$, higher corrosion potential values were registered, in comparison with those of the untreated alloy, but localized corrosion phenomena were well observable, mainly in the area shielded by the gasket. It may be hypothesized that these corrosion phenomena were related to the heterogeneous structure formed by $\gamma_{\mathrm{N}}$ and h.c.p. phase $\left(\varepsilon_{\mathrm{N}}{ }^{\prime}\right.$ martensite and/or nitride precipitates), which tended to hinder repassivation.

Author Contributions: Conceptualization, F.B., E.G. and T.B.; Formal analysis, F.B. and E.G.; Investigation, F.B. and E.G.; Writing-original draft preparation, F.B.; Writing—review and editing, F.B. and E.G.; Supervision, F.B.; Project administration, F.B.; Funding acquisition, F.B. and T.B. All authors have read and agreed to the published version of the manuscript.

Funding: This research was funded by MIUR (Ministero dell'Istruzione, dell'Università e della Ricerca; years 2015, 2016, 2017).

Data Availability Statement: Data is contained within the article.

Conflicts of Interest: The authors declare no conflict of interest. 


\section{References}

1. Washko, S.D.; Aggen, G. Wrought Stainless Steels. In ASM Handbook Vol. 1; ASM International: Materials Park, OH, USA, 1997; pp. 841-907.

2. Johnson, J.; Reck, B.K.; Wang, T.; Graedel, T.E. The energy benefit of stainless steel recycling. Energy Policy 2008, 36, 181-192. [CrossRef]

3. Charles, J. The new 200 Series: An alternative answer to Ni surcharge? Dream or nightmare? In Proceedings of the Stainless Steel '05, Proceedings of the Fifth Stainless Steel Science and Market Congress, Sevilla, Spain, 27-30 September 2005; Odriozola, J.A., Paúl, A., Eds.; Centro de Investigaciones Científicas Isla de la Cartuja: Sevilla, Spain, 2005; pp. 19-27.

4. Talha, M.; Behera, C.K.; Sinha, O.P. A review on nickel-free nitrogen containing austenitic stainless steels for biomedical applications. Mater. Sci. Eng. C 2013, 33, 3563-3575. [CrossRef] [PubMed]

5. Yang, K.; Ren, Y. Nickel-free austenitic stainless steels for medical applications. Sci. Technol. Adv. Mater. 2010, 11, 14105. [CrossRef]

6. Sumita, M.; Hanawa, T.; Teoh, S.H. Development of nitrogen-containing nickel-free austenitic stainless steels for metallic biomaterials-review. Mater. Sci. Eng. C 2004, 24, 753-760. [CrossRef]

7. Lo, K.H.; Shek, C.H.; Lai, J.K.L. Recent developments in stainless steels. Mater. Sci. Eng. R Rep. 2009, 65, 39-104. [CrossRef]

8. Patnaik, L.; Maity, S.R.; Kumar, S. Status of nickel free stainless steel in biomedical field: A review of last 10 years and what else can be done. Mater. Today Proc. 2020, 26, 638-643. [CrossRef]

9. Thomann, U.I.; Uggowitzer, P.J. Wear-corrosion behavior of biocompatible austenitic stainless steels. Wear 2000, 239, 48-58. [CrossRef]

10. Reclaru, L.; Ziegenhagen, R.; Eschler, P.Y.; Blatter, A.; Lemaître, J. Comparative corrosion study of “Ni-free" austenitic stainless steels in view of medical applications. Acta Biomater. 2006, 2, 433-444. [CrossRef]

11. Bell, T. Current Status of Supersaturated Surface Engineered S-Phase Materials. Key Eng. Mater. 2008, 373-374, 289-295. [CrossRef]

12. Christiansen, T.L.; Somers, M.A.J. Low-temperature gaseous surface hardening of stainless steel: The current status. Z. Fuer Met. Res. Adv. Tech. 2009, 100, 1361-1377. [CrossRef]

13. Dong, H. S-phase surface engineering of Fe-Cr, Co-Cr and Ni-Cr alloys. Int. Mater. Rev. 2010, 55, 65-98. [CrossRef]

14. Collins, S.R.; Williams, P.C.; Marx, S.V.; Heuer, A.; Ernst, F.; Kahn, H. Low-Temperature Carburization of Austenitic Stainless Steels. In ASM Handbook Vol. 4D.; Dosset, J., Totten, G.E., Eds.; ASM International: Materials Park, OH, USA, 2014 ; pp. 451-460.

15. Borgioli, F. From Austenitic Stainless Steel to Expanded Austenite-S Phase: Formation, Characteristics and Properties of an Elusive Metastable Phase. Metals 2020, 10, 187. [CrossRef]

16. Williamson, D.L.; Ozturk, O.; Wei, R.; Wilbur, P.J. Metastable phase formation and enhanced diffusion in f.c.c. alloys under high dose, high flux nitrogen implantation at high and low ion energies. Surf. Coat. Technol. 1994, 65, 15-23. [CrossRef]

17. Cardoso, R.P.; Mafra, M.; Brunatto, S.F. Low-temperature Thermochemical Treatments of Stainless Steels-An Introduction. In Plasma Science and Technology_Progress in Physical States and Chemical Reactions; Mieso, T., Ed.; InTech: Rijeka, Croatia, 2016; pp. 107-130; ISBN 978-953-51-2280-7. [CrossRef]

18. Somers, M.; Kücükyildiz, Ö.; Ormstrup, C.; Alimadadi, H.; Hattel, J.; Christiansen, T.; Winther, G. Residual Stress in Expanded Austenite on Stainless Steel; Origin, Measurement, and Prediction. Mater. Perform. Charact. 2018, 7, 693-716. [CrossRef]

19. Christiansen, T.; Somers, M.A.J. Controlled dissolution of colossal quantities of nitrogen in stainless steel. Metall. Mater. Trans. A 2006, 37, 675-682. [CrossRef]

20. Fossati, A.; Borgioli, F.; Galvanetto, E.; Bacci, T. Glow-discharge nitriding of AISI 316L austenitic stainless steel: Influence of treatment time. Surf. Coat. Technol. 2006, 200, 3511-3517. [CrossRef]

21. Christiansen, T.L.; Ståhl, K.; Brink, B.K.; Somers, M.A.J. On the Carbon Solubility in Expanded Austenite and Formation of Hägg Carbide in AISI 316 Stainless Steel. Steel Res. Int. 2016, 87, 1395-1405. [CrossRef]

22. Sun, Y.; Li, X.; Bell, T. Low temperature plasma carburising of austenitic stainless steels for improved wear and corrosion resistance. Surf. Eng. 1999, 15, 49-54. [CrossRef]

23. Bell, T. Surface engineering of austenitic stainless steel. Surf. Eng. 2002, 18, 415-422. [CrossRef]

24. Luo, Q.; Oluwafemi, O.; Kitchen, M.; Yang, S. Tribological properties and wear mechanisms of DC pulse plasma nitrided austenitic stainless steel in dry reciprocating sliding tests. Wear 2017, 376-377, 1640-1651. [CrossRef]

25. Liu, Z.; Zhang, S.; Wang, S.; Peng, Y.; Gong, J.; Somers, M.A.J. On the fatigue behavior of low-temperature gaseous carburized 316L austenitic stainless steel: Experimental analysis and predictive approach. Mater. Sci. Eng. A 2020, 793, 139651. [CrossRef]

26. Borgioli, F.; Galvanetto, E.; Bacci, T. Corrosion behaviour of low temperature nitrided nickel-free, AISI 200 and AISI 300 series austenitic stainless steels in $\mathrm{NaCl}$ solution. Corros. Sci. 2018, 136, 352-365. [CrossRef]

27. Borgioli, F.; Fossati, A.; Raugei, L.; Galvanetto, E.; Bacci, T. Low temperature glow-discharge nitriding of stainless steels. In Proceedings of the 7th European Stainless Steel Conference: Science and Market, Como, Italy, 21-23 September 2011; Associazione Italiana di Metallurgia: Milan, Italy, 2011.

28. Buhagiar, J.; Li, X.; Dong, H. Formation and microstructural characterisation of S-phase layers in Ni-free austenitic stainless steels by low-temperature plasma surface alloying. Surf. Coat. Technol. 2009, 204, 330-335. [CrossRef]

29. Buhagiar, J.; Qian, L.; Dong, H. Surface property enhancement of Ni-free medical grade austenitic stainless steel by lowtemperature plasma carburising. Surf. Coat. Technol. 2010, 205, 388-395. [CrossRef] 
30. Formosa, D.; Hunger, R.; Spiteri, A.; Dong, H.; Sinagra, E.; Buhagiar, J. Corrosion behaviour of carbon S-phase created on Ni-free biomedical stainless steel. Surf. Coat. Technol. 2012, 206, 3479-3487. [CrossRef]

31. Buhagiar, J. Plasma Surface Engineering and Characterisation of Biomedical Stainless Steels. Ph.D. Thesis, University of Birmingham, Birmingham, UK, 2008.

32. Borgioli, F.; Galvanetto, E.; Bacci, T. Surface modification of austenitic stainless steel by means of low pressure glow-discharge treatments with nitrogen. Coatings 2019, 9, 604. [CrossRef]

33. Borgioli, F.; Galvanetto, E.; Bacci, T. Effects of surface modification by means of low temperature plasma nitriding on wetting and corrosion behavior of austenitic stainless steel. Coatings 2020, 10, 98. [CrossRef]

34. Bondarenko, A.S.; Ragoisha, G.A. Inverse Problem in Potentiodynamic Electrochemical Impedance. In Progress in Chemometrics Research; Pomerantsev, A.L., Ed.; Nova Science Publishers, Inc.: New York, NY, USA, 2005; pp. 89-102.

35. Lei, M.K. Phase transformations in plasma source ion nitrided austenitic stainless steel at low temperature. J. Mater. Sci. 1999, 34, 5975-5982. [CrossRef]

36. Borgioli, F.; Galvanetto, E.; Bacci, T. Low temperature nitriding of AISI 300 and 200 series austenitic stainless steels. Vacuum 2016, 127, 51-60. [CrossRef]

37. Lei, M.K.; Huang, Y.; Zhang, Z.L. In situ Transformation of Nitrogen-induced h.c.p. Martensite in Plasma Source Ion-nitrided Austenitic Stainless Steel. J. Mater. Sci. Lett. 1998, 17, 1165-1167. [CrossRef]

38. Czerwiec, T.; He, H.; Marcos, G.; Thiriet, T.; Weber, S.; Michel, H. Fundamental and Innovations in Plasma Assisted Diffusion of Nitrogen and Carbon in Austenitic Stainless Steels and Related Alloys. Plasma Process. Polym. 2009, 6, 401-409. [CrossRef]

39. Tong, K.; Ye, F.; Che, H.; Lei, M.K.; Miao, S.; Zhang, C. High-density stacking faults in a supersaturated nitrided layer on austenitic stainless steel. J. Appl. Crystallogr. 2016, 49, 1967-1971. [CrossRef]

40. Fewell, M.P.; Priest, J.M. High-order diffractometry of expanded austenite using synchrotron radiation. Surf. Coat. Technol. 2008, 202, 1802-1815. [CrossRef]

41. Bou-Saleh, Z.; Shahryari, A.; Omanovic, S. Enhancement of corrosion resistance of a biomedical grade 316LVM stainless steel by potentiodynamic cyclic polarization. Thin Solid Films 2007, 515, 4727-4737. [CrossRef]

42. Abreu, C.M.; Cristóbal, M.J.; Merino, P.; Nóvoa, X.R.; Pena, G.; Pérez, M.C. Electrochemical behaviour of an AISI 304L stainless steel implanted with nitrogen. Electrochim. Acta 2008, 53, 6000-6007. [CrossRef]

43. Omanovic, S.; Roscoe, S.G. Electrochemical Studies of the Adsorption Behavior of Bovine Serum Albumin on Stainless Steel. Langmuir 1999, 15, 8315-8321. [CrossRef]

44. Jorcin, J.-B.; Orazem, M.E.; Pébère, N.; Tribollet, B. CPE analysis by local electrochemical impedance spectroscopy. Electrochim. Acta 2006, 51, 1473-1479. [CrossRef]

45. Jüttner, K. Electrochemical impedance spectroscopy (EIS) of corrosion processes on inhomogeneous surfaces. Electrochim. Acta 1990, 35, 1501-1508. [CrossRef]

46. Bai, H.; Wang, F. Protective Properties of High Temperature Oxide Films on Ni-based Superalloys in 3.5\% NaCl Solution. J. Mater. Sci. Technol. 2007, 23, 541-546.

47. Tao, X.; Li, X.; Dong, H.; Matthews, A.; Leyland, A. Evaluation of the sliding wear and corrosion performance of triode-plasma nitrided Fe-17Cr-20Mn-0.5N high-manganese and Fe-19Cr-35Ni-1.2Si high-nickel austenitic stainless steels. Surf. Coat. Technol. 2021, 409, 126890. [CrossRef]

48. Egawa, M.; Ueda, N.; Nakata, K.; Tsujikawa, M.; Tanaka, M. Effect of additive alloying element on plasma nitriding and carburizing behavior for austenitic stainless steels. Surf. Coat. Technol. 2010, 205, S246-S251. [CrossRef]

49. Christiansen, T.; Somers, M.A.J. Low temperature gaseous nitriding and carburising of stainless steel. Surf. Eng. 2005, 21, 445-455. [CrossRef]

50. Stinville, J.C.; Cormier, J.; Templier, C.; Villechaise, P. Modeling of the lattice rotations induced by plasma nitriding of 316L polycrystalline stainless steel. Acta Mater. 2015, 83, 10-16. [CrossRef]

51. Yakubtsov, I.A.; Ariapour, A.; Perovic, D.D. Effect of nitrogen on stacking fault energy of f.c.c. iron-based alloys. Acta Mater. 1999, 47, 1271-1279. [CrossRef]

52. Talonen, J.; Hänninen, H. Formation of shear bands and strain-induced martensite during plastic deformation of metastable austenitic stainless steels. Acta Mater. 2007, 55, 6108-6118. [CrossRef]

53. Tao, X.; Qi, J.; Rainforth, M.; Matthews, A.; Leyland, A. On the interstitial induced lattice inhomogeneities in nitrogen-expanded austenite. Scr. Mater. 2020, 185, 146-151. [CrossRef]

54. Tao, X.; Liu, X.; Matthews, A.; Leyland, A. The influence of stacking fault energy on plasticity mechanisms in triode-plasma nitrided austenitic stainless steels: Implications for the structure and stability of nitrogen-expanded austenite. Acta Mater. 2019, 164, 60-75. [CrossRef]

55. Lee, Y.-K.; Choi, C. Driving force for $\gamma \rightarrow \varepsilon$ martensitic transformation and stacking fault energy of $\gamma$ in Fe-Mn binary system. Metall. Mater. Trans. A 2000, 31, 355-360. [CrossRef]

56. Fossati, A.; Galvanetto, E.; Bacci, T.; Borgioli, F. Improvement of corrosion resistance of austenitic stainless steels by means of glow-discharge nitriding. Corros. Rev. 2011, 29, 209-221. [CrossRef]

57. Chao, K.L.; Liao, H.Y.; Shyue, J.J.; Lian, S.S. Corrosion behavior of high nitrogen nickel-free Fe-16Cr-Mn-Mo-N stainless steels. Metall. Mater. Trans. B Process. Metall. Mater. Process. Sci. 2014, 45, 381-391. [CrossRef] 
58. Sun, S.; Wei, S.; Wang, G.; Jiang, Z.; Lian, J.; Ji, C. The Synthesis and Electrochemical Behavior of High-Nitrogen Nickel-Free Austenitic Stainless Steel. J. Mater. Eng. Perform. 2014, 23, 3957-3962. [CrossRef]

59. Afonso, M.L.C.d.A.; Jaimes, R.F.V.V.; Nascente, P.A.P.; Rogero, S.O.; Agostinho, S.M.L. Surface characterization, electrochemical behaviour and cytotoxicity of UNS S31254 stainless steel for orthopaedic applications. Mater. Lett. 2015, 148, 71-75. [CrossRef] 